\title{
Metoda matematycznego modelowania układu pneumatycznego hamulca pojazdu szynowego
}

$W$ artykule zaprezentowano wtasna metode modelowania elementów uktadu pneumatycznego hamulca pojazdu szynowego. Bazuje ona na podziale uktadu na dyskretne elementy, wybraniu procedur modelowania z opracowanego pakietu modeli, zautomatyzowanym złożeniu w układ i rozwiqzaniu poprzez symulacje czasowq. Metoda symulacyjna uwzględnia specyfikę modelowania elementów składowych kolejowych układów hamulcowych. Przedstawiono ogólny zarys zaproponowanej metody, paletę modeli i ich krótkie opisy, opis zmiennych numerycznych, danych modelu i metodę rozwiazania. Artykut powstat $w$ wyniku realizacji projektu badawczego KBN nr $5 T 12 C 03025$ pt. „Badania procesów zachodzacych w pneumatycznych uktadach hamulcowych pociqgów".

\section{Symbole i oznaczenia}

A

$A_{z}$

$c$

$c_{p}$

$c_{v}$

$c_{w}, c_{z}$

$D$
$d_{r}$

$d_{t} \quad$ współczynnik zasadniczego tłumienia thumika

$d_{s}$. współczynnik szeregowego tłumienia wiskotycznego

$d x \quad$ elementarny przyrost długości przewodu

dzwignia przełożenie dźwigni

$\dot{E} \quad$ strumień energii gazu

$F \quad$ siła w elemencie (może być oznaczona odpowiednim indeksem)

$F c_{k} \quad$ siła wypadkowa działająca na k-tą masę

$f(u) \quad$ współczynnik oporu tarcia przewodu

$i_{0}, i_{1} \quad$ entalpia gazu wlotowego i wylotowego

$M_{x} \quad$ współczynnik prędkości krytycznej

$\dot{m} \quad$ masowe natężenie przepływu

$\dot{m}_{*_{t}} \quad$ izentropowe maksymalne masowe natężenie

przepływu dla prędkości krytycznej

masa $_{i} \quad$ wartość i-tej masy

$p, \dot{p} \quad$ ciśnienie gazu i jego pochodna po czasie (może być oznaczone odpowiednim indeksem)

pojc

pow $_{i}$

$\dot{q}$ pojemność cieplna zbiornika powierzchnia membrany (ze znakiem + lub - ) strumień ciepła przepływający przez ścianki zbiornika (może być oznaczony indeksem) stała gazowa

sygnał sterowania

sztywność równoległa

sztywność szeregowa $t_{o p}$

$t_{\mathrm{s}}$

$u$

$u_{k}$

V

wspstr

$x, \dot{x}, \ddot{x}$

$x_{0}$

$x_{\text {max }}$

$x_{s}$

$x_{t}$

$x_{z}$

$z m d_{l}$

$\beta$

$\beta_{k r}$

$\beta_{k r 2}$

$\Phi$

$\kappa$

$\lambda$

$\mu$

$\mu_{* *}$

$\rho, \dot{\rho}$

0 sztywność sprężyny głównej

aktualna temperatura gazu

temperatura otoczenia

temperatura ścianek zbiornika, jej pochodna po

czasie

czas

opóźnienie sterowania

zadana długość czasu sterowania

prędkość rzeczywista gazu

prędkość krytyczna gazu

objętość zbiornika lub cylindra (może być oznaczone odpowiednim indeksem)

współczynnik straty entalpii na zaworze

przemieszczenie masy lub ugięcie elementu

oraz ich pochodne po czasie

skok początkowy tłoka

skok maksymalny tłoka

ugięcie elementu szeregowego

ugięcie elementu zasadniczego (zależne od procedury)

zadany luz początkowy sprężyny

zmienna dodatkowa (specyficzna dla niektórych procedur)

stosunek ciśnień

krytyczny stosunek ciśnień

drugi krytyczny stosunek ciśnień (wartość stała)

średnica przelotu

wykładnik izentropy

współczynnik oporu przepływu

współczynnik kontrakcji dyszy lub zaworu

współczynnik wydatku drugiej prędkości krytycznej

gęstość i jej pochodna po czasie (może być oznaczona odpowiednim indeksem) indeks wlotu w równaniach przepływu indeks wylotu w równaniach przepływu 


\section{Wstęp}

Współczesne pojazdy szynowe mogą dysponować kilkoma rodzajami hamulców, jednak hamulec pneumatyczny jest dotychczas zawsze głównym hamulcem klasycznych pociagów osobowych i towarowych. Pomimo ponad półtora wiekowej eksploatacji takich hamulców nadal trwa ich rozwój techniczny, a nowoczesne rozwiązania konstrukcji wagonów i sterowania pociagiem stwarzają konieczność projektowania nowych elementów również dla tego układu. Układ pneumatyczny hamulca pociagu jest układem rozległym rozmiarowo oraz skomplikowanym. Jest to układ, w którym zasadniczą rolę odgrywają zjawiska dynamiki przepływu gazu oraz dynamiki elementów mechanicznych. Analizować go można poprzez badania na układach rzeczywistych pociagu, stanowiskach próbnych bądź poprzez badania symulacyjne [3]. Ze względów ekonomicznych najbardziej efektywne są badania symulacyjne, które dla układów pneumatycznych hamulców pojazdów i pociągu są rozwijane od kilku lat i ciagle doskonalone.

Pneumatyczny układ hamulcowy jest na tyle skomplikowany, że omawiana metoda modelowania została podzielona na dwa obszary modelu układu hamulcowego:

- całopociagowego modelu hamulca; podstawowe problemy tego modelu przedstawiono w [4],

- szczegółowego modelu dla poszczególnych układów pneumatyczno-mechanicznych.

Obydwa obszary modelowania przenikają się $\mathrm{w}$ wybranych wariantach symulacyjnych i moga utworzyć jeden całościowy, najdokładniejszy model. W niniejszym artykule przedstawiono obecny stan rozwoju cześci problematyki, obejmujący opis metody modelowania szczegółowego układów pneumatycznomechaniczno-elektrycznych zwany dalej pakietem modelowania BLOK. Artykuł zawiera ogólny opis wszystkich elementów składowych pakietu; część mechaniczną przedstawiono bardziej szczegółowo w [6]. Dalsze szczegółowe rozważania i dyskusja metod zostaną dokonane w kolejnych publikacjach.

\section{Opis ogólny pakietu BLOK}

\subsection{Zastosowania metody symulacyjnej i jej wa- rianty}

Metoda jest oparta na komputerowej metodzie obliczeń symulacyjnych opracowanej z myślą o analizie układów typu: elementy sterujące, przepływowe, pojemnościowe i siłowe wraz $\mathrm{z}$ instalacjami pneumatycznymi. Procedury obliczeniowe opracowano na takim poziomie szczegółowości, że umożliwiają symulację pracy urządzeń z dokładnością wystarczającą do prac konstrukcyjnych.

Prezentowana metoda symulacyjna jest pakietem spójnych procedur: opisu matematycznego modeli elementów składowych (zwanych blokami), podprogramów scalających, sterowania, rozwiązania równań, wprowadzania danych i wyprowadzania wyników obliczeń. Zadaniem użytkownika jest zamiana konstrukcji układu rzeczywistego na jego model, przekazanie opisu konfiguracji modelu układu dynamicznego do programu symulacyjnego, określenie jego parametrów liczbowych oraz żądanej formy wydruku wyników. Pozostałe etapy nie wymagają ingerencji merytorycznej użytkownika.

Cechy kolejowego układu hamulcowego są następujące:

- zawiera elementy pneumatyczne, mechaniczne oraz coraz częściej elektryczne, występujące w różnych kombinacjach,

- posiada skomplikowane funkcje pracy, objawiające się spełnianiem przez jego elementy więcej niż jednej funkcji w zależności od dynamiki zmiennych procesu,

- zmienność procesów jest dobraną celowo funkcją czasu,

- sterowanie jest liniowe (ciagłe).

Modelowanie części pneumatycznej posiada stopień uproszczenia, w którym objętości układu pneumatycznego i elementy dławienia przepływu takie jak: dysze, krótkie przewody, opory lokalne przepływu opisuje się w postaci dyskretnych elementów zawartych $\mathrm{w}$ blokach. Jedynie długie przewody pneumatyczne opisywane są jako oddzielne dyskretne bloki, wewnątrz których przepływ gazu opisywany jest jako zjawisko ciagłe zdyskretyzowane, uwzględniające $m$. in. zjawiska falowe. We wszystkich elementach uwzględniono ściśliwość gazu, a w zależności od rodzaju elementu założono przemianę adiabatyczną, izotermiczną bądź analizowano wymianę ciepła. W elementach przepływowych założono przepływy jednowymiarowe gazu doskonałego i niewystępowanie prędkości nadkrytycznych.

Oprócz bloków pneumatycznych w omawianej metodzie zamodelowane są również bloki opisujące dynamikę mas dyskretnych: siły sprężystości, tłumienia, bezwładności, ograniczenia ruchu oraz bloki wspólne dla układu pneumatycznego i mechanicznego: membrany, zawory pneumatyczne, cylindry o objętości zmieniającej się wraz z ruchem tłoka.

Pakiet zawiera również elementy umożliwiające symulację układów sterowania elektrycznego połączonych z układem pneumatycznym lub mechanicznym.

Wyniki symulacji, które otrzymuje się w postaci plików liczbowych, można przetworzyć przy pomocy odrębnie opracowanego oprogramowania na forme graficzną - wykresy przebiegów ciśnień i przemieszczeń w funkcji czasu wybranych wyników symulacji.

W trakcie opracowania omawianej metody utworzono przedstawioną gamę elementów składowych; zakłada się możliwość tworzenia nowych elementów, na które pojawi się zapotrzebowanie w trakcie użytkowego wykorzystywania metody. Idea metody jest jej użyteczność, dlatego przygotowano procedury 
o różnej dokładności opisu. Przeważnie model bardziej ogólny umożliwia opis bardziej dokładny, ale wymaga większego nakładu obliczeń numerycznych i istnieje dodatkowe ryzyko popelnienia błędu przez nieumiejętne modelowanie. Modele cząstkowe są prostsze, zakładaja zadane uproszczenia. Zbiór opracowanych elementów składowych ukierunkowany jest na zagadnienia analizy hamulców i zawiera opisy specyficznych elementów konstrukcyjnych, jak np. cylindrów hamulcowych. Metoda jest jednak uniwersalna, może być również wykorzystana do analizy innych układów pneumatyczno-mechanicznych.

Prezentowana metoda przewidziana jest do wykorzystania $\mathrm{w}$ dwóch zasadniczych wariantach:

- jako pakiet autonomiczny analizy jednego dyskretnego układu pneumatyczno-mechanicznego (nazwany BLOK),

- jako część pakietu symulacji całopociagowego układu hamulcowego; zasadniczą jego częścią jest przewód główny modelowany odrębną metodą elementów skończonych (MES), a dołączyć do niego można wielokrotnie różne układy pneumatycznomechaniczne, np. zawór maszynisty, zawory rozrządcze $\mathrm{z}$ wagonowymi układami hamulcowymi. W wersji tej dołączono również modele elementów ciernych hamulca, pozwalające na symulację hamowania pociągów łącznie $\mathrm{z}$ dynamiką wzdłużną pociagu sztywnego (w takiej analizie nie uwzględnia się podatności urządzeń pociągowo-zderznych).

Dodatkowe, rozszerzone wersje obu wariantów pozwalają na identyfikację parametrów modelu metodą optymalizacji nieliniowej na podstawie wyników badań doświadczalnych.

W zależności od celu analiz można utworzyć układ o różnym stopniu szczegółowości. W przypadku rozważania układu całowagonowego przeważnie nie są istotne procesy zachodzące w ułamkach sekundy, natomiast opis załączania przekładnika bądź przyspieszacza zaworu rozrządczego wymaga analiz w krótkich przedziałach czasowych. Wszystkich tych analiz można by dokonać tym samym modelem całopociągowym, jednak to się nie opłaca. Przygotowanie pełnego, możliwie najdokładniejszego modelu jest zajęciem żmudnym i czasochłonnym. Dlatego w analizach całopociągowych sugeruje się korzystać z elementów uproszczonych, a do analiz szczegółowych tworzyć układy mniejsze rozmiarowo, ale dokładniejsze. Do pakietu w jego wersji całopociągowej planuje się dołączenie gotowych modeli zaworów rozrządczych stosowanych w Polsce.

Układy hamulcowe realizują procesy wywołane nieokresowymi sterowaniami, dlatego analizuje się pracę tego układu jedynie jako procesy przejściowe $\mathrm{w}$ funkcji czasu przez obliczenie odpowiedzi układu w kolejnych chwilach czasowych, poprzez całkowanie numeryczne pochodnych zmiennych procesu.

\subsection{Cechy metody}

Układ pneumatyczno-mechaniczny opisywany jest jako zbiór elementów dyskretnych (w przypadku elementów pneumatycznych o znacznej rozciągłości wykorzystuje się MES, traktując element jako zdyskretyzowany). Zmienne układu podzielono na zmienne stanu, zmienne przepływowe oraz zmienne sterowania; według innego podziału na pneumatyczne, mechaniczne i elektryczne. Przykładowo rozpatrując zmienne mechaniczne (i wykorzystując nazewnictwo teorii grafów):

- zmiennymi mechanicznymi stanu (węzłów grafu) są przemieszczenia, prędkości i przyspieszenia,

- zmiennymi mechanicznymi przepływowymi (odno-

szącymi się do krawędzi grafu) są siły międzyele-

mentowe.

Zmienne przepływowe opisane są nieliniowymi funkcjami stanu w funkcji zmiennych lokalnych poszczególnych bloków, a następnie są łączone $\mathrm{z}$ wszystkich bloków w zmienne globalne i służą do określenia stanu układu.

W układzie dynamicznym mogą istnieć: zderzaki, sprężyny o charakterystykach skokowych lub zawory o zmiennym otwarciu, dlatego zmienne układu nie zawsze będą posiadały pierwszą pochodną ciagłą po czasie. W związku z tym zastosowano jednokrokowa metodę całkowania o stałym lub zmiennym kroku obliczeń.. Sterowanie symulacją polega na utworzeniu pliku zawierającego zmienne sterujące, konfigurację układu, parametry liczbowe modelu oraz sterowanie wydrukiem wyników.

Podprogram sterujący wywołuje symulacyjne procedury przepływowe i węzłowe pracy układu na podstawie danych konfiguracji układu. W wyniku otrzymuje się chwilowe wartości liczbowe pochodnych wszystkich zmiennych głównych układu po czasie. Następnie dokonywane jest całkowanie, dla zmiennych pneumatycznych jednokrotne, a dla zmiennych mechanicznych dwukrotne. Zmienne elektryczne sa określane zależnościami algebraicznymi.

Podstawową cechą pakietu programów jest przyjęta ujednolicona metoda opisu parametrów oraz zmiennych układu, a wnikając w głąb programu, ujednolicony sposób przekazywania tych wartości przez podprogramy. Zasada ta umożliwia łatwe dopisywanie dalszych podprogramów. Tabela 1 przedstawia wyszczególnienie procedur modelowania pakietu BLOK.

Użyte nazewnictwo konkretnych procedur odpowiada bezpośrednio nazwom użytym w programie napisanym w języku Fortran; nie zawsze odpowiada ono regułom języka polskiego. 
Elementy modelowania układów pneumatyczno-mechanicznych

Tabela 1

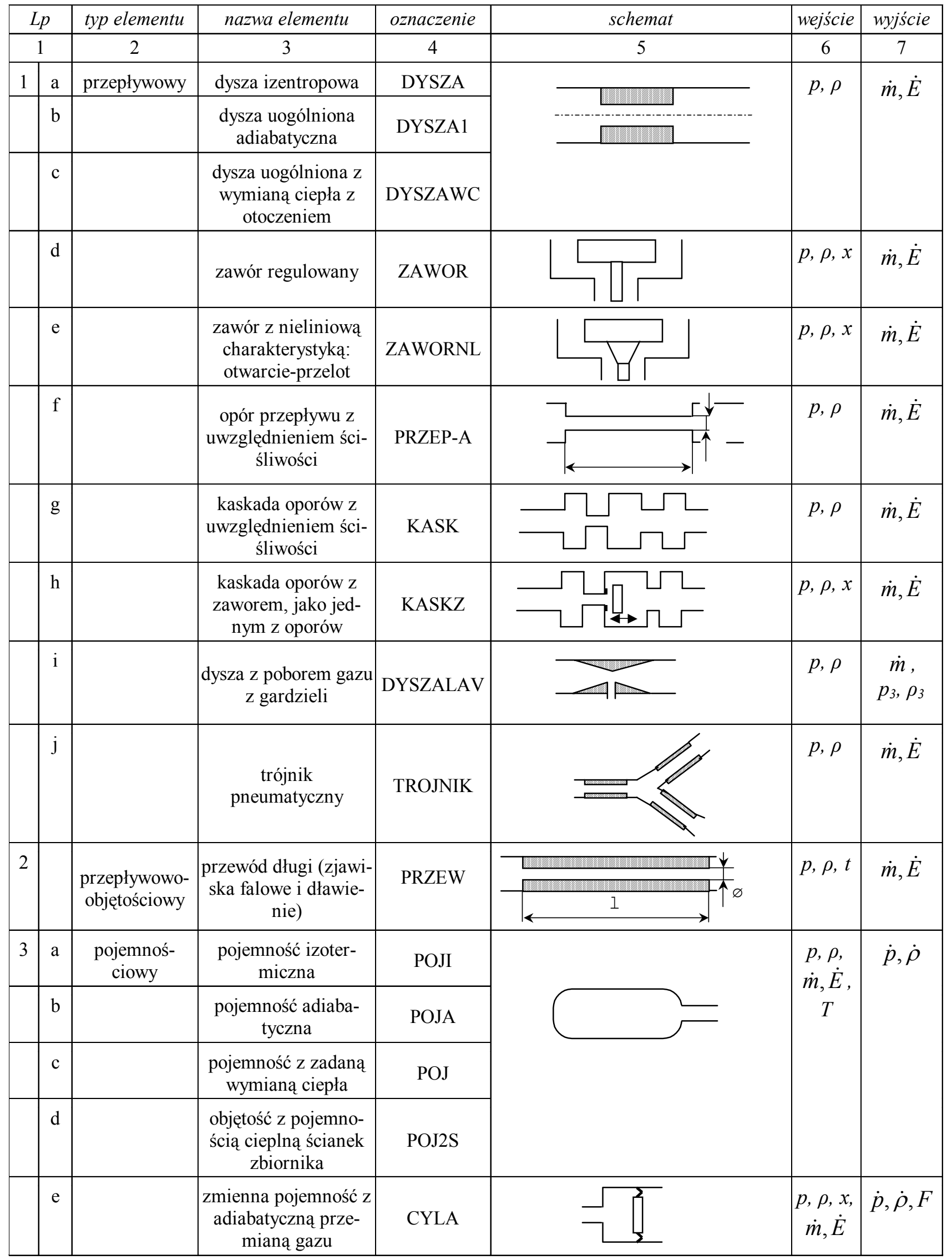


c.d. tabeli 1

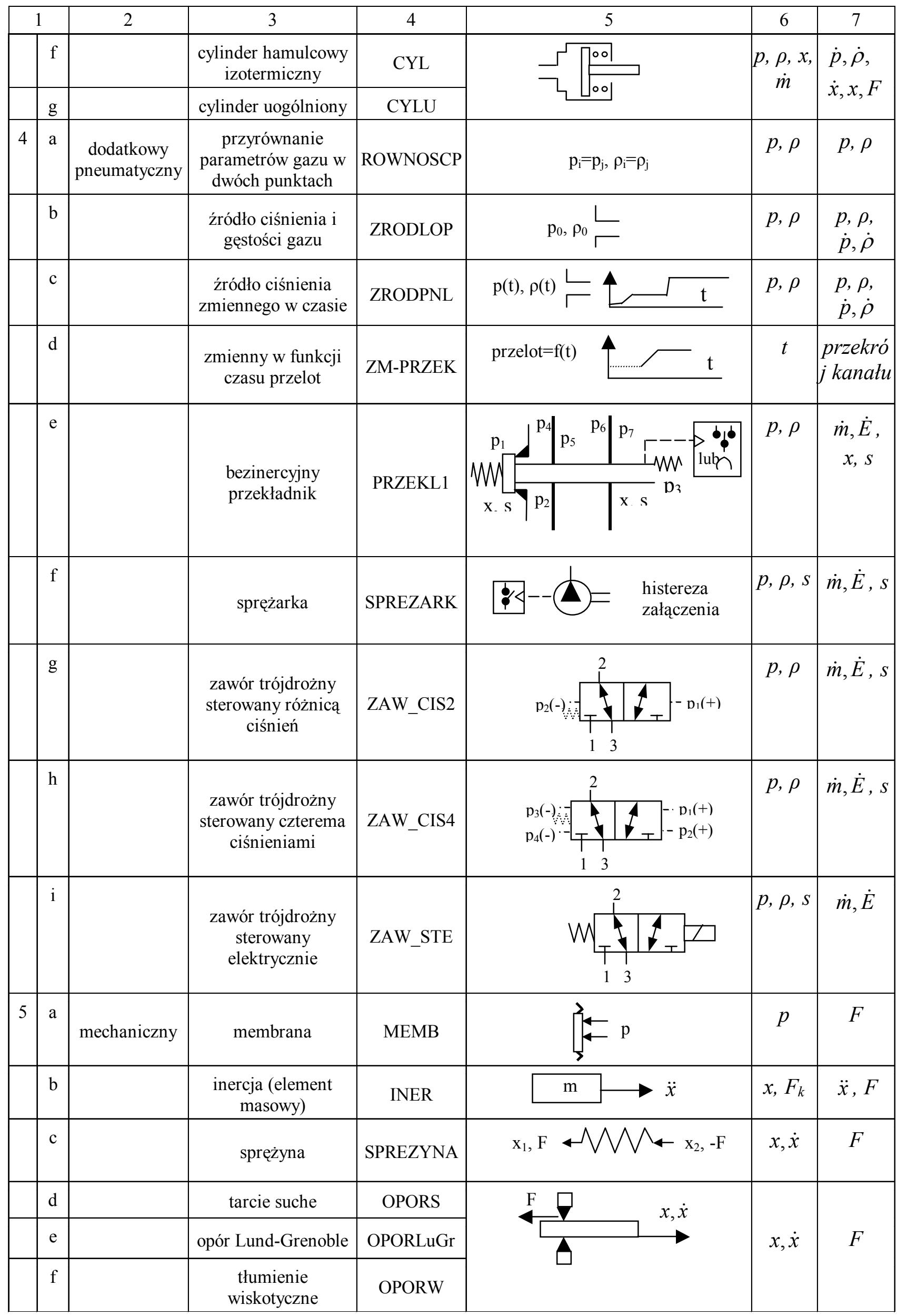


c.d. tabeli 1

\begin{tabular}{|c|c|c|c|c|c|c|c|}
\hline 1 & 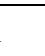 & 2 & 3 & 4 & 5 & 6 & 7 \\
\hline & $\mathrm{g}$ & & dźwignia & DZWIGNIA & $\mathrm{F}_{\mathrm{i}} \stackrel{\downarrow}{\downarrow} \mathrm{F}_{\mathrm{j}}$ & $F_{i}$ & $F_{j}$ \\
\hline & $\mathrm{h}$ & & źródło siły & ZRODLOS & $\mathrm{F}$ & brak & $F$ \\
\hline & $\mathrm{i}$ & & źródło siły nieliniowe & ZRODSNL & $\rightarrow \mathrm{F}=\mathrm{F}(\mathrm{t})$ & $t$ & $F$ \\
\hline & $\mathrm{j}$ & & $\begin{array}{c}\text { źródło } \\
\text { przemieszczenia }\end{array}$ & ZRODLOX & $x$ & brak & $x, \dot{x}$ \\
\hline & $\mathrm{k}$ & & $\begin{array}{c}\text { źródło } \\
\text { przemieszczenia } \\
\text { nieliniowe } \\
\end{array}$ & ZRODXNL & $x=x(t)$ & $t$ & $x, \dot{x}$ \\
\hline & 1 & & $\begin{array}{c}\text { ogranicznik ruchu } \\
\text { (zderzak) }\end{array}$ & ZDERZ & & $x, \dot{x}, \ddot{x}$ & $x, \dot{x}$ \\
\hline & $\mathrm{m}$ & & $\begin{array}{l}\text { zblokowanie ruchu } \\
\text { dwóch mas }\end{array}$ & $\begin{array}{c}\text { ROWNOSC } \\
\mathrm{X}\end{array}$ & $\mathrm{x}_{2}$ & $x, \dot{x}, \ddot{x}$ & $x, \dot{x}, F$ \\
\hline 6 & $\mathrm{a}$ & sterowania & $\begin{array}{l}\text { zmienny w czasie } \\
\text { sygnał sterowania }\end{array}$ & ZM_STER & & $t$ & $S$ \\
\hline & $\mathrm{b}$ & & $\begin{array}{l}\text { generator sterowania } \\
\text { impulsowego }\end{array}$ & STIMPULS & 4 & $t$ & $s$ \\
\hline & $\mathrm{c}$ & & $\begin{array}{l}\text { opóźnienie } \\
\text { sterowania }\end{array}$ & OPSTE & wejście & $s, t$ & $S$ \\
\hline & $\mathrm{d}$ & & $\begin{array}{l}\text { sterowanie o zadanej } \\
\text { długości czasu }\end{array}$ & DLSTE & \begin{tabular}{c} 
wejście \\
\hdashline$\quad$ wyjście \\
-1
\end{tabular} & $s, t$ & $S$ \\
\hline & $\mathrm{e}$ & & \multirow{4}{*}{ Elementy logiczne } & LOGAND & \multirow{4}{*}{$\begin{array}{lll}\triangleright \text { AND }> & \Delta \text { OR } \\
\Delta \text { NOT } P & \triangleright \text { XOR } \\
\triangleright{ }^{2}\end{array}$} & \multirow[t]{4}{*}{$s$} & \multirow[t]{4}{*}{$S$} \\
\hline & $\mathrm{f}$ & & & LOGOR & & & \\
\hline & $\mathrm{g}$ & & & LOGNOT & & & \\
\hline & $\mathrm{h}$ & & & LOGXOR & & & \\
\hline
\end{tabular}

\section{Tworzenie modelu}

Utworzenie modelu symulacyjnego dokonywane jest w kilku etapach. Najpierw należy rozłożyć projekt obiektu rzeczywistego na elementy składowe dyskretne odpowiadające tabeli 1 (dyskretyzacja modelu). Następnie należy ponumerować wszystkie węzły pneumatyki, pojemności układu, siły, masy, sterowania itd. tworząc topografię układu. Następnie tworzy się plik danych do programu. Na jego podstawie automatycznie tworzony jest i rozwiązywany układ równań modelu.

\subsection{Topografia modelu}

Topografię układu przedstawiono przy pomocy kilku układów oznaczeń, dla których wprowadzono nieliczne ograniczenia.
- Układ punktów pneumatyki - uwzględnia się wszystkie punkty układu pneumatycznego, w których gaz posiada określone parametry (znane lub obliczane). Kolejność numeracji punktów jest dowolna poza nielicznymi wyjątkami. Nie wszystkie punkty muszą być wykorzystane.

- Układ wydatków masowych - strumienie powietrza wszystkich elementów przepływowych wchodzących w skład układu, takich jak: dysze, zawory, kaskady oporów, długie przewody itp. Poszczególne elementy są kolejno numerowane.

- Układ objętości - w wymienionych objętościach program dokona obliczenia (całkowania) stanu gazu.

- Układ sił składowych - użytkownik definiuje 
wszystkie siły skupione występujące w rozpatrywanym układzie, działające na elementy ruchome. Siłę parcia gazu na każdą powierzchnię (z jednej strony) np. membranę zastępuje się siłą skupioną. Do sił składowych przypisuje się także siły d'Alemberta.

- Układ elementów ruchomych - każdy stopień swobody (całkowalny) ruchu elementów mechanicznych ma przypisany numer zmiennej. Ponieważ układ jest jednowymiarowy, jeden stopień swobody przypisany jest do każdego ruchomego elementu mechanicznego.

- Układ zmiennych dodatkowych - niektóre elementy wymagaja wprowadzenia dodatkowych zmiennych całkowanych $\mathrm{w}$ procesie symulacyjnym.

\subsection{Dane wezytywane przez program}

Wszystkie dane zawarte są $\mathrm{w}$ jednym pliku. Plik ten składa się z kilku części:

- dane sterujące określające zakres czasu obliczeń, dobór kroku obliczeń, krok wydruku,

- ilość grup danych liczbowych modelu,

- dane liczbowe modelu układu (podawane jako zbiór liczb rzeczywistych, może on być nadmiarowy $\mathrm{w}$ stosunku do struktury modelu; zmiana struktury modelu nie wymaga więc zmian w danych liczbowych),

- struktura modelu (opisana w postaci nazw wywoływanych bloków i liczb sterujących),

- zakres wyników zamieszczanych w plikach wydruku.

\subsection{Układ równań opisujących model}

Główny układ równań modelu jest następujący.

Część pneumatyczna:

- równania zachowania energii układu otwartego,

- równania zachowania masy układu otwartego.

Część mechaniczna:

- równania równowagi dynamicznej sił (zasada d'Alemberta).

Część sterująca:

- ewentualne równania logiczne łączących się sygnałów sterujących.

Jako zmienne niezależne układu przyjęto:

$p_{j}$ - ciśnienie gazu w objętościach $(j-$ bieżący indeks objętości),

$\rho_{j}$ - gęstości gazu w objętościach,

$x_{k}$ - przemieszczenia elementów ruchomych $(k-$ bieżący indeks przemieszczenia),

$z m d_{l}$ - zmienne dodatkowe (specyficzne dla niektórych procedur), ( $l$ - bieżący indeks zmiennej dodatkowej).

Zmiennymi pomocniczymi, wynikającymi ze zmiennych niezależnych układu są: $\dot{m}_{i}$ - składowe strumienie masy gazu $(i$ - bieżący indeks strumienia gazu),

$\dot{E}_{i}$ - składowe strumienie energii gazu,

$\dot{E}_{j}$ - sumaryczne strumienie energii gazu,

$\dot{m}_{j}$ - sumaryczne strumienie masy gazu wpadające do j-tej objętości,

$F_{k}$ - sumaryczne siły działające na $k$-tym przemieszczeniu.

$F_{n}$ - składowe siły działające w układzie ( $n-$ bieżący indeks siły składowej).

Tworzenie końcowego układu równań różniczkowych odbywa się w następującej kolejności:

1. Określenie ciśnień, gęstości gazu oraz sił wprowadzonych $\mathrm{z}$ zewnątrz. Zalicza się do nich stałe lub zmienne w czasie tzw. źródła ciśnienia lub siły działające spoza układu.

2. Określenie składowych zmiennych przepływowych:

- strumieni masy $\dot{m}_{i}$,

- strumieni energii $\dot{E}_{i}$,

- sił międzyelementowych $F_{n}$,

- pochodnych zmiennych dodatkowych $z m d_{l}$.

Zależności te są wyliczane w poszczególnych blokach opisu układu.

3. Określenie sumarycznych (wypadkowych) zmiennych przepływowych działających na zmienne niezależne układu. Sumowanie następuje po wskazanych zmiennych składowych $\mathrm{z}$ uwzględnieniem znaku:

$$
\dot{m}_{j}=\sum \dot{m}_{i}, \quad \dot{E}_{j}=\sum \dot{E}_{i}, \quad F_{k}=\sum F_{i} .
$$

Odrębne istnienie zmiennych składowych nie jest konieczne; zachowano je w celu możliwości kontroli pracy analizowanego układu.

4. Określenie pochodnych dla głównych zmiennych

$$
\frac{d p_{j}}{d t} ; \frac{d \rho_{j}}{d t}, \frac{d \dot{x}_{k}}{d t} .
$$

5. Uwzględnienie ograniczeń wprowadzonych w układzie jak: zderzaków, zblokowanych mas itp.

\section{Procedury sterujące i obsługi pakietu}

Zadaniem tych procedur jest organizacja obliczeń, wczytanie danych i konfiguracji, prowadzenie procesu obliczeń i wyprowadzanie wyników.

- Program główny - jest to program główny o nazwie BLOK, którego zadaniem jest uruchomienie obliczeń i sterowanie nimi.

- Wczytanie konfiguracji układu i danych liczbowych.

- Procedura sterowania - steruje obliczeniami poprzez wywoływanie poszczególnych bloków.

- Dobór kroku obliczeń. Modele mechaniczno pneumatyczne mogą składać się z członów funkcjonalnych o znacznie zróżnicowanych chwilo- 
wych wartościach własnych. Dla zapewnienia dokładności obliczeń wymagany krok obliczeń musi być mniejszy od kryterium Nyquista. Dla układu nieliniowego, wartość ta może zmieniać się na każdym kroku obliczeń. Przy obliczeniach ze stałym krokiem jego wartość zadaje się jednorazowo, należy przyjąć najmniejszy wymagany krok. W momentach, gdy nie jest wymagany tak mały krok wydłuża się znacznie czas obliczeń. Załączana opcjonalnie procedura pozwala na automatyczny dobór długości kroku obliczeń. W przypadku symulacji opieranie się na wartościach własnych dla doboru kroku obliczeń jest kłopotliwe; wybrano szybszą metodę polegającą na zapewnieniu małego odchylenia od liniowości na każdym kroku obliczeń.

- Rozwiązanie układu równań dynamiki podprogram ten rozwiązuje układ równań, całkując jednokrotnie zależności pneumatyczne i zmiennych pomocniczych, a dwukrotnie mechaniczne.

- Obliczenie sumarycznego strumienia masy. W specyficznych analizach pożądana jest także znajomość sumarycznego strumienia masy przepływającego gazu od początku symulacji.

- Wydruk wyników. Wyniki symulacji gromadzone są w kilku plikach według listy zadanej parametrami sterującymi:

- plik dokumentacyjny, zawiera zinterpretowany przez program zbiór danych wejściowych oraz wyniki symulacji $\mathrm{z}$ krokiem dziesięciokrotnie dłuższym, niż w pozostałych plikach.

- pliki z wynikami symulacji; wyniki podzielono na dwa pliki w celu uniknięcia zbyt długich wierszy w jednym pliku. Do wizualizacji wyników można wykorzystać przygotowane programy graficzne,

- w trakcie symulacji wybrane wyniki wyświetlane są na ekranie monitora.

\section{Opis elementów pneumatycznych}

\subsection{Elementy przepływowe}

W zależności od wymaganej dokładności symulacji i równocześnie znajomości charakterystyki elementów przepływowych można wykorzystać modele elementów przepływowych o różnej dokładności ich opisu.

\subsubsection{Dysza izentropowa}

Dla opisu pracy standardowych dysz stosowanych w układach pneumatycznych proponuje się wykorzystanie zależności na dysze izentropowe [12], zmodyfikowane o współczynnik kontrakcji. Procedura ta nosi nazwę DYSZA.

Dla przepływu izentropowego przez dysze stosunek ciśnień $\beta=\frac{p_{1}}{p_{0}}$ osiaga wartość krytyczną dla:

$$
\beta_{k r}=\left(\frac{p_{1}}{p_{0}}\right)_{\max }=\left(\frac{2}{\kappa+1}\right)^{\frac{\kappa}{\kappa-1}}
$$

Masowe natężenie przepływu przyjmuje dla przepływu podkrytycznego wartość:

$$
\dot{m}=\mu \cdot A \cdot \sqrt{p_{0} \cdot \rho_{0}} \cdot \sqrt{\frac{2 \cdot \kappa}{\kappa-1}} \cdot \sqrt{\left(\frac{p_{1}}{p_{0}}\right)^{\frac{2}{\kappa}}-\left(\frac{p_{1}}{p_{0}}\right)^{\frac{\kappa+1}{\kappa}}}
$$

Dla stosunku ciśnień $\beta$ większego niż krytyczny:

$$
\dot{m}=\mu \cdot A \cdot \sqrt{p_{0} \cdot \rho_{0}} \cdot \sqrt{\frac{2 \cdot \kappa}{\kappa-1}} \cdot \sqrt{\left(\frac{2}{\kappa+1}\right)^{\frac{2}{\kappa-1}}-\left(\frac{2}{\kappa+1}\right)^{\frac{\kappa+1}{\kappa-1}}}
$$

Strumień energii dany jest zależnością:

$$
\dot{E}=\dot{m} \cdot i_{0}=\dot{m} \cdot c_{p} \cdot T=\dot{m} \cdot \frac{\kappa}{\kappa-1} \cdot R \cdot T=\dot{m} \cdot \frac{\kappa}{\kappa-1} \cdot \frac{p_{0}}{\rho_{0}}
$$

Należy zaznaczyć, że użycie pojęcia „izentropowy” dotyczy wlotu i przepływu w dyszy. Wyloty z dysz sa przeważnie ostrokrawędziowe $\mathrm{i}$ następuje $\mathrm{w}$ nich zaburzony wylot gazu z jego dławieniem i stratą entropii.

\subsubsection{Dysza uogólniona adiabatyczna}

Rzeczywiste przepływy przez elementy dławiące, zwłaszcza przez kryzy i zawory, charakteryzują się przesunięciem punktu krytycznego przepływu. Dla modelowania takiego przepływu utworzono element „dysza uogólniona” DYSZA1.

Maksymalny strumień masy w dyszy rzeczywistej osiagany dla niższego, niż dla dyszy izentropowej stosunku ciśnień, oznaczono przez $\beta_{k r 2}$.

Charakterystykę przelotowości otworu można określić wg [2] tylko na podstawie doświadczalnej. Na podstawie uogólnionych danych doświadczalnych, można ją wyrazić w funkcji $\xi$ [2]:

$$
\xi=\frac{\beta-\beta_{k r 2}+(1-\beta) \cdot \beta_{k r}}{1-\beta_{k r 2}}
$$

w postaci:

$$
\dot{m}=q_{1} \mu_{* *} \dot{m}_{*_{t}},
$$

gdzie:

$$
\begin{aligned}
& q_{1}=\left(\frac{\kappa+1}{2}\right)^{\frac{1}{\kappa-1}} \xi^{\frac{1}{\kappa}} \sqrt{\frac{\kappa+1}{\kappa-1}\left[1-\xi^{\frac{\kappa-1}{\kappa}}\right]} \\
& \dot{m}_{*_{t}}=A \sqrt{\kappa \cdot p_{1} \cdot \rho_{1}}\left(\frac{2}{\kappa+1}\right)^{\frac{\kappa+1}{2(\kappa-1)}}
\end{aligned}
$$

Współczynnik wydatku drugiej prędkości krytyczıеj $\mu_{* *}$ jest zależny od kształtu przelotu. 
Dla małej różnicy ciśnień końców dyszy wpływ tarcia teoretycznie winien być znaczniejszy i dlatego wprowadzono dodatkowy opcjonalny współczynnik proporcjonalności (uzyskany na podstawie badań), pozwalający zmniejszać efektywny przekrój dyszy do postaci:

$$
A=A\left(p_{0}, p_{1}\right)
$$

Jest to zależność aproksymowana, stosowana dla stosunku ciśnień $\beta$ większego, niż zadany.

\subsubsection{Dysza uogólniona $z$ wymianą ciepła $z$ oto- czeniem}

Doświadczenia wykonywane na różnych rodzajach hamulcowej aparatury pneumatycznej wykazały niekiedy pewną niedoskonałość procedury DYSZA1. W związku z tym utworzono nowy element układu symulacyjnego - dyszę uogólnioną $\mathrm{z}$ wymianą ciepła $\mathrm{z}$ otoczeniem (DYSZAWC).

Zależności na masowe natężenie przepływu są identyczne, jak dla dyszy uogólnionej adiabatycznej; entalpia na wlocie posiada wartość:

$$
i_{0}=\frac{\kappa}{\kappa-1} \cdot \frac{p_{0}}{\rho_{0}}
$$

Entalpia gazu wylotowego $i_{1}$ określona jest uproszczoną zależnością przyjętą na podstawie badań:

$$
i_{1}=i_{0} \cdot(1-\text { wspstr })
$$

Różnica entalpii wpływającej do dyszy i wypływającej z niej jest stratą energii rozpraszanej do obudowy zaworu i otoczenia, nie bilansowanej dalej w układzie.

\subsubsection{Zawory}

Zawór jest elementem dławienia przepływu, w którym przelot powietrza przez zawór jest funkcją zadawanego z zewnątrz przemieszczenia elementu sterującego.

W przepływie przez zawór uwzględniono przesunięcie wartości krytycznego stosunku ciśnień. Zastosowano zależności przepływowe uproszczoną funkcją eliptyczną [12]; dla przepływu podkrytycznego, po przekształceniach, przyjmuje ona postać:

$\dot{m}=A \cdot \mu \cdot \sqrt{\kappa \cdot p_{1} \cdot \rho_{1}}\left(\frac{2}{\kappa+1}\right)^{\frac{\kappa+1}{2(\kappa-1)}} \cdot \sqrt{1-\left(\frac{\left(p_{1} / p_{0}\right)-\beta^{\prime}}{1-\beta^{\prime}}\right)^{2}}$

W prezentowanej metodzie symulacyjnej utworzono dwa modele zaworów:

- model o liniowej zmianie przelotu gazu w funkcji otwarcia zaworu (prostszy) i ograniczeniu przelotu maksymalnego ZAWOR,

- model o nieliniowej zmienności przelotu w funkcji otwarcia zaworu, spowodowanej np. geometrią trzona zaworu i podatnością uszczelnień, o nazwie ZAWORNL. Kształt charakterystyki wczytuje się w postaci charakterystycznych punktów łamanej, co pokazano na rys. 1 .
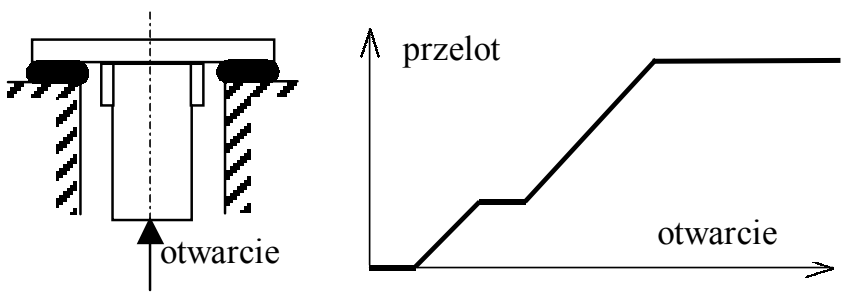

Rys. 1. Przykładowy zaworek z nieliniową funkcją otwarcie-przelot

\subsubsection{Dyskretne szeregowe elementy oporu prze- pływu}

Przewody dławiące przepływ gazu złożone $\mathrm{z}$ szeregu elementów o zmiennym przekroju, różnych kształtach wlotów i wylotów, cechujące się znacznymi oporami przepływu, są jednymi z głównych składników układów pneumatycznych. Zamodelowano je również w omawianym pakiecie. Przeważnie cechuje je mała objętość w stosunku do objętości komór je łączących, można je zatem przyjąć jako elementy bez objętości. Gaz przy przepływie przez element oporowy może znacznie zmienić swe parametry, należy więc uwzględnić jego ściśliwość. Założono brak możliwości przejścia przepływu $\mathrm{w}$ nadkrytyczny. Przy układach o znacznych różnicach ciśnień na końcach przewodów i zmiennym przekroju możliwe jest powstanie przepływów krytycznych także w pośrednich punktach przewodów.

Dla przedstawionego pakietu blokowego zaproponowano metodę rozwiązania opartą o zasadę prowadzenia analizy „z prądem”, a w przypadku wystapienia przepływu teoretycznie „nadkrytycznego" dokonanie efektywnej iteracji dla osiagnięcia przepływu krytycznego. Ponieważ przepływ zbliżony do laminarnego wystapi bardzo rzadko, przyjęto zależności dla przepływu burzliwego. Opracowany algorytm obliczeń przepływów przez kaskadę oporów składa się z kilku cześci, a metoda bazuje na analizie przepływu metoda kolejnych przybliżeń. Obliczenia numeryczne są stabilne także przy przepływach zbliżonych do krytycznego, gdy występują bardzo silne nieliniowości. Ze względu na iteracje, proces obliczeniowy jest dłuższy, niż dla procedur dysz.

Układ równań jednowymiarowego przepływu ga$\mathrm{zu}$, przy niezmienności procesu w czasie i braku wymiany ciepła $\mathrm{z}$ otoczeniem, ma dla każdego odcinka przewodu o stałym przekroju postać $[1,11]$ :

$\int_{0}^{1} \lambda \frac{d x}{D}=\frac{\kappa+1}{2 \kappa} \cdot\left(\frac{1}{M_{x 0}^{2}}+2 \cdot \ln M_{x 0}\right)-\frac{\kappa+1}{2 \kappa} \cdot\left(\frac{1}{M_{x 1}^{2}}+2 \cdot \ln M_{x 1}\right)$

gdzie:

$$
M_{x}=\frac{u}{u_{k}}
$$


Omawiane przepływy opisane są następującymi procedurami pakietu BLOK:

- pojedynczy adiabatyczny element oporu przepływu PRZEP-A,

- kaskada adiabatycznych elementów oporu przepływu bez pośrednich elementów objętościowych KASK.

- kaskada KASKZ o zależnościach identycznych jak KASK $\mathrm{z}$ tym, że jednym $\mathrm{z}$ jej elementów jest zawór o sterowanym przelocie.

\subsubsection{Dysza z poborem gazu z gardzieli}

Sterowanie układu pneumatycznego ciśnieniem pobieranym z gardzieli dyszy zbieżno-rozbieżnej (dysza Lavala) wstawionej w kanale przepływowym stosuje się czasem dla uzależnienia sterowania od masowego natężenia przepływu i uzyskania ciśnienia sterowania nieznacznie niższego od ciśnienia w danym punkcie przewodu pneumatycznego (lp. $1 \mathrm{i}$ w tabeli 1). Charakterystyka dyszy zbieżno-rozbieżnej jest trudna do określenia [12], dlatego model oparty jest na dobieranych indywidualnie współczynnikach. Omawiany element opisano procedurą DYSZALAV. Różni się ona od modelu dyszy adiabatycznej w jej części wylotowej. Założono, że w części rozbieżnej dyszy do przekroju o zadanej wielkości $A_{z}$ przepływ jest izentropowy, poza nim przepływ jest dławiony.

Zagadnienie jest rozwiązywane metodą kolejnych przybliżeń ze względu na ciśnienie wylotowe $p_{2}$.

Najpierw sprawdza się, czy w układzie występują parametry krytyczne, obliczając maksymalny strumień masowy

$$
\dot{m}_{\max }=\mu \cdot A_{\min } \cdot \sqrt{p_{0} \cdot \rho_{0}} \cdot \sqrt{\frac{2 \cdot \kappa}{\kappa-1}} \cdot \sqrt{\left(\frac{2}{\kappa+1}\right)^{\frac{2}{\kappa-1}}-\left(\frac{2}{\kappa+1}\right)^{\frac{\kappa+1}{\kappa-1}}}
$$

Następnie oblicza się ciśnienie $p_{z}$, które powstałoby w zadanym przekroju dyfuzora $\mathrm{A}_{\mathrm{z}}$ :

$$
\left(\frac{p_{z}}{p_{0}}\right)^{\frac{2}{\kappa}}-\left(\frac{p_{z}}{p_{0}}\right)^{\frac{\kappa+1}{\kappa}}=\left(\frac{\dot{m}}{A_{z} \cdot \sqrt{p_{0} \cdot \rho_{0}} \cdot \sqrt{\frac{2 \cdot \kappa}{\kappa-1}}}\right)^{2}
$$

Jeżeli to ciśnienie jest wyższe niż ciśnienie w zbiorniku wylotowym, oznacza to, że przepływ jest krytyczny i ciśnienie $\mathrm{w}$ gardzieli osiaga wartość minimalną $p_{1}$ obliczaną z zależności:

$$
\frac{p_{1}}{p_{0}}=\left(\frac{2}{\kappa+1}\right)^{\frac{\kappa}{\kappa-1}}
$$

W przeciwnym przypadku przepływ jest podkrytyczny i masowe natężenie przepływu ma wartość:

$$
\dot{m}=A_{z} \cdot \sqrt{p_{0} \cdot \rho_{0}} \cdot \sqrt{\frac{2 \cdot \kappa}{\kappa-1}} \cdot \sqrt{\left(\frac{p_{z}}{p_{0}}\right)^{\frac{2}{\kappa}}-\left(\frac{p_{z}}{p_{0}}\right)^{\frac{\kappa+1}{\kappa}}}
$$

a ciśnienie $\mathrm{w}$ gardzieli osiaga wartość $p_{1}$ obliczaną $\mathrm{z}$ równania:

$$
\left(\frac{p_{1}}{p_{0}}\right)^{\frac{2}{\kappa}}-\left(\frac{p_{1}}{p_{0}}\right)^{\frac{\kappa+1}{\kappa}}=\left(\frac{\dot{m}}{\mu \cdot A_{\min } \cdot \sqrt{p_{0} \cdot \rho_{0}} \cdot \sqrt{\frac{2 \cdot \kappa}{\kappa-1}}}\right)^{2}
$$

Zakłada się, że strumień masy gazu wpływającego w odgałęzienie jest niewielki i nie jest brany pod uwage w bilansie masy.

\subsubsection{Trójnik pneumatyczny}

Połączenie w jednym węźle trzech elementów przepływowych (odgałęzienie lub trójnik) jest elementem często stosowanym $\mathrm{w}$ aparaturze pneumatycznej. W celu obliczenia przepływu standardową metoda pakietu, należałoby wprowadzić dodatkową objętość w miejscu połączenia tych elementów. Zaproponowano odrębną metodę rozwiązania zagadnienia elementem o nazwie TROJNIK. Schemat układu przedstawiono na rys. 2 (indeksy $1 \div 3$ oznaczają przyłączone oporami przepływu elementy objętościowe), a parametry gazu w węźle $p_{4}$ i $\rho_{4}$ są wyliczane w procedurze.

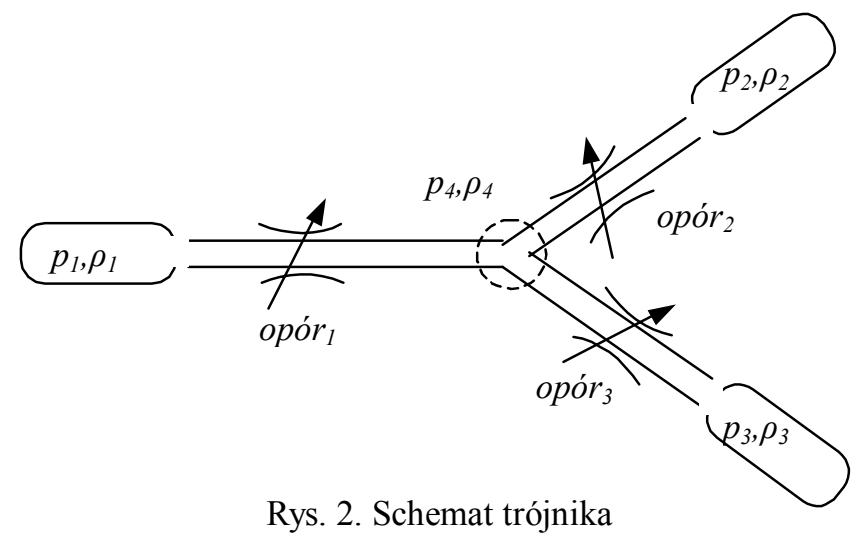

Elementami oporowymi trójnika mogą być dysze lub zawory (ze zmiennym otwarciem). Dławienie przelotu może być silnie nieliniowe, dlatego zastosowano metodę kolejnych przybliżeń. Pomocniczo wylicza się parametry gazu w węźle środkowym i na tej podstawie przepływy w poszczególnych gałęziach. W każdym kroku przybliżenia wykorzystuje się linearyzację dla aktualnych zmiennych układu.

Metoda jest zbieżna zarówno dla przebiegów podkrytycznych i krytycznych a także wtedy, gdy zamykano przelot $\mathrm{w}$ jednej $\mathrm{z}$ gałęzi.

\subsubsection{Przewód długi - element uwzględniający zjawiska falowe i dlawienie}

Jest to element metody symulacji układów pneumatyczno-mechanicznych (o nazwie PRZEW), który posiada $\mathrm{z}$ założenia zadaną skończoną długość i zachodzą w nim zjawiska falowe. Dla metody BLOK istotne jest tylko określenie parametrów gazu i wyliczenie zmienności wydatku na końcach przewodu, jednakże przepływ gazu jest analizowany na całej długości przewodu. 
Układ równań różniczkowych na postać:

- równanie ciągłości

$$
\frac{\partial \rho}{\partial t}+\rho \cdot \frac{\partial u}{\partial x}+u \cdot \frac{\partial \rho}{\partial x}=0
$$

- równanie pędu

$$
\frac{\partial u}{\partial t}+u \cdot \frac{\partial u}{\partial x}+\frac{1}{\rho} \cdot \frac{\partial p}{\partial x}-a \cdot f(u)=0
$$

- równanie energii

$$
-q \cdot d x=\frac{\partial}{\partial t}\left[\rho \cdot A \cdot\left(c_{v} \cdot T+\frac{u^{2}}{2}\right)\right] \cdot d x+\frac{\partial}{\partial x}\left[\rho \cdot A \cdot u \cdot\left(c_{p} \cdot T+\frac{u^{2}}{2}\right)\right] \cdot d x=0
$$

- równanie stanu

$$
p=\rho \cdot R \cdot T
$$

Układ równań rozwiązywany jest metodą elementów skończonych (MES) przy zadanych wartościach brzegowych. Wykorzystano wcześniej opracowaną dla analizy przewodu głównego MES [4], dokonując jej uproszczeń. Użycie tego elementu może być przyczyną znacznego wydłużenia obliczeń symulacyjnych.

\subsection{Pojemności układu}

W pakiecie BLOK zaproponowano elementy objętościowe (zbiorniki gazu) o różnym stopniu dokładności. Opisano również procedury uproszczone, gdyż są one szybsze i bardziej stabilne. W zbiornikach założono brak deformacji objętościowej, gdyż stalowe ścianki zbiorników i sztywne węże hamulcowe pozwalaja na przyjęcie tego założenia. Analizując opróżniania lub napełniania zbiornika można wybrać różne modele wymiany ciepła $\mathrm{z}$ otoczeniem.

Odrębną grupę stanowią elementy pojemnościowe o zmiennej objętości zadanej wymuszoną deformacją jednej ze ścian. Są to np. cylindry hamulcowe $\mathrm{z}$ tłokami jak również komory zamknięte membranami.

\subsubsection{Pojemność izotermiczna}

Jest to pojemność $\mathrm{z}$ idealną wymianą ciepła pomiędzy zgromadzonym $\mathrm{w}$ zbiorniku gazem a jego ściankami (i otoczeniem), dając przemianę izotermiczna. Model nazwano POJI. Stosowanie tej procedury jest korzystne w uproszczonych analizach, w których ważny jest ostateczny bilans przepływu gazu przy stale otwartym połączeniu objętości.

Zmiany parametrów gazu $\mathrm{w}$ zbiorniku dla przemiany izotermicznej (indeks pi) zostały opisane zależnością:

$$
\begin{aligned}
& \dot{\rho}_{p i}=\dot{m} / V_{p i} \\
& \dot{p}_{p i}=R \cdot T_{0} \cdot \dot{m} / V_{p i}
\end{aligned}
$$

\subsubsection{Pojemność adiabatyczna}

Jest to pojemność bez wymiany ciepła pomiędzy zgromadzonym w zbiorniku gazem, a jego ściankami (przemiana adiabatyczna). Model nazwano POJA. Stosowanie tej procedury jest korzystne $\mathrm{w}$ uproszczonych analizach, w których ważny jest chwilowy stan gazu w objętości w procesach szybkozmiennych.

Zmiany parametrów gazu w zbiorniku dla przemiany adiabatycznej (indeks pa) opisane zostały zależnościami:

$$
\begin{aligned}
& \dot{\rho}_{p a}=\dot{m} / V_{p a} \\
& \dot{p}_{p a}=\dot{E} \cdot(\kappa-1) / V_{p a}
\end{aligned}
$$

\subsubsection{Pojemność $z$ wymianą ciepła pomiędzy ga- zem a ściankami zbiornika}

Jest to pojemność z zadanym współczynnikiem wymiany ciepła pomiędzy zgromadzonym $\mathrm{w}$ nim gazem, a jego ściankami (i otoczeniem). Model nazwano POJ (indeks ${ }_{\mathrm{ps}}$ ). Założono, że wymiana ciepła między gazem w zbiorniku a jego ściankami jest wprost proporcjonalna do różnicy temperatur gazu w zbiorniku i otoczeniu, przyjmując postać:

$$
m \cdot c_{v} \cdot \frac{d p_{p s}}{\rho_{p s} \cdot R}=c \cdot\left(T-T_{0}\right) \cdot d t+\dot{m}_{w} \cdot i_{w} \cdot d t
$$

i ostatecznie:

$$
\begin{aligned}
& \dot{\rho}_{p s}=\dot{m} / V_{p s} \\
& \dot{p}_{p s}=\frac{(\kappa-1)}{V_{p s}} \cdot(\dot{q}+\dot{E}) \\
& T=\frac{p_{p s}}{\rho_{p s} \cdot R} \\
& \dot{q}=c \cdot\left(T-T_{0}\right)
\end{aligned}
$$

\subsubsection{Objętość $\mathrm{z}$ pojemnością cieplną ścianek zbiornika}

Jest to objętość $\mathrm{z}$ zadaną pojemnością cieplną ścianek zbiornika oraz zadanymi współczynnikami wymiany ciepła pomiędzy: zgromadzonym w zbiorniku gazem a jego ściankami oraz odrębnie pomiędzy ściankami zbiornika, a otoczeniem. Model nazwano POJ2S (indeks ${ }_{\mathrm{p} 2 \mathrm{~s}}$ ).

W modelu pojawia się dodatkowo pojemność cieplna ścianek zbiornika oraz dodatkowa zmienna (temperatura ścianek zbiornika). Podstawowe zależności modelu przyjmują postać:

$$
\begin{aligned}
& \dot{q}_{w}=c_{w}\left(T_{s}-T\right) \\
& \dot{q}_{z}=c_{z}\left(T_{s}-T_{o}\right) \\
& \dot{\rho}_{p 2 s}=\dot{m} / V_{p 2 s} \\
& \dot{p}_{p 2 s}=\frac{(\kappa-1)}{V_{p 2 s}} \cdot\left(\dot{q}_{w}+\dot{E}\right) \\
& \dot{T}_{s}=\frac{\left(-\dot{q}_{w}-\dot{q}_{z}\right)}{p o j c_{s}}
\end{aligned}
$$


gdzie: ${ }_{\text {w }}$ - indeks powierzchni wewnętrznej zbiornika, $z_{z}$ - indeks powierzchni zewnętrznej zbiornika.

\subsubsection{Zmienna pojemność $\mathrm{z}$ adiabatyczną prze- mianą gazu}

Zbiornik powietrza o zmiennej pojemności $\mathrm{z}$ adiabatyczną przemianą gazu w jego wnętrzu nazwano w opisywanym pakiecie cylindrem adiabatycznym (CYLA, indeks ca). Element ten przewidziano głównie jako modelujący przestrzenie wewnątrz aparatury pneumatycznej np. przekładników, pojemności zamknięte $\mathrm{z}$ jednej strony membraną itp.

Dla modelu cylindra adiabatycznego przyjęto zależności:

$$
\begin{aligned}
& V_{c a}=\left(x_{0}+x\right) \cdot A \\
& \dot{\rho}_{c a}=\frac{\dot{m}}{V_{c a}}-\frac{\rho_{c a}}{V_{c a}} \dot{V}_{c a} \\
& \dot{p}_{c a}=\dot{m}_{w} \cdot \frac{\kappa}{V_{c a}} \cdot R T_{w}-\frac{\kappa \cdot p_{c a}}{x+x_{0}} \dot{x} \\
& F_{c a}=\left(p_{c a}-p_{a t m}\right) \cdot A
\end{aligned}
$$

\subsubsection{Cylinder hamulcowy izotermiczny}

Element o zmiennej objętości nazywa się często w literaturze siłownikiem, cylindrem lub serwomotorem. Kompletny zespół cylindra o budowie analogicznej do cylindra kolejowego i wbudowaną sprężyną powrotną, z uproszczeniami wystarczającymi do analiz bilansu gazu i sił hamowania nazwano CYL; jego schemat przedstawiono na rys. 3 . Założono w nim przemianę izotermiczna, co dla stalowych cylindrów hamulców kolejowych $\mathrm{w}$ normalnych warunkach pracy (napelnianie do wyrównania ciśnień lub zadanego ciśnienia, np. zaworem maksymalnego ciśnienia) i analiz hamowności jest uzasadnione. Pominięto masowe siły bezwładności oraz tarcie w cylindrze, gdyż normalnie są one niewielkie.

Model omawianego cylindra izotermicznego posiada trzy zakresy pracy:

Zakres 1. Dla małych ciśnień tłok znajduje się w skrajnym położeniu minimalnej objętości wymuszonym dociskiem sprężyny i ogranicznikiem ruchu. Objętość ta składa się z objętości resztkowej cylindra i pojemności przewodu dolotowego. Równania stanu gazu są podobne, jak dla pojemności izotermicznej.

Zakres 2. Przy wzrastającym, ale ciagle małym ciśnieniu w cylindrze następuje ruch tłoka, którego położenie wynika $\mathrm{z}$ równowagi ciśnień, a pośrednio $\mathrm{z}$ masy gazu wpływającej do cylindra. Zakres ten jest w przypadku układu hamulcowego etapem przejściowym, w którym następuje proces przesuwania się elementów wykonawczych hamulca aż do przylgnięcia par ciernych do kół, ma więc mniejsze znaczenie, jeżeli chodzi o sam proces hamowania, ważny jest natomiast bilans masy-energii gazu.

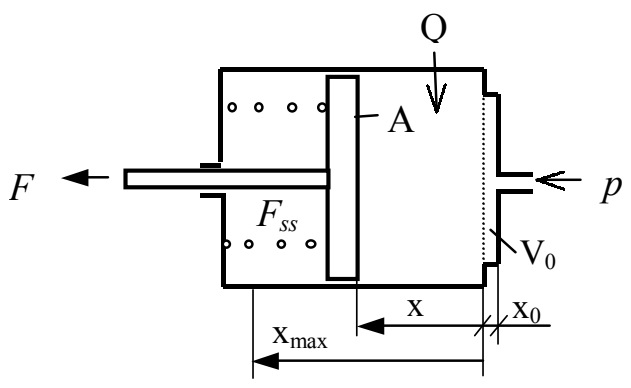

Rys. 3. Schemat cylindra hamulcowego

Wyjściowe równania układu mają postać:

$$
\begin{aligned}
& V_{c i}=\left(x_{0}+x\right) \cdot A \\
& p_{c i}=p_{x 0}+\frac{p_{x \max }-p_{x 0}}{x_{\max }} \cdot x \\
& \rho_{c i}=\frac{p_{c i}}{R T_{0}}
\end{aligned}
$$

gdzie:

ci indeks cylindra izotermicznego,

xo indeks początku ruchu tłoka cylindra,

xmax indeks końca ruchu tłoka cylindra.

Równanie masy gazu po podstawieniu zależności na ciśnienie ma postać:

$$
\begin{aligned}
& m=\frac{A}{R \cdot T_{0}}\left(p_{x 0} \cdot x_{0}+p_{x 0} \cdot x+\frac{p_{x \max }-p_{x 0}}{x_{\max }} x_{0} \cdot x+\right. \\
& \left.+\frac{p_{x \max }-p_{x 0}}{x_{\max }} x^{2}\right)
\end{aligned}
$$

Po zróżniczkowaniu względem czasu i uporządkowaniu otrzymuje się zależności końcowe:

$$
\begin{aligned}
& \dot{x}=\frac{R T_{0}}{A} \frac{\dot{m}}{\left(p_{x 0}+\frac{p_{x \max }-p_{x 0}}{x_{\max }} x_{0}+2 \frac{p_{x \max }-p_{x 0}}{x_{\max }} x\right)} \\
& \dot{p}_{c i}=\frac{p_{x \max }-p_{x 0}}{x_{\text {max }}} \cdot \dot{x} \\
& \dot{\rho}_{c i}=\frac{\dot{p}_{c i}}{R T_{0}}
\end{aligned}
$$

Siła zewnętrzna trzona tłokowego ma wartość:

$$
F_{c i} \cong 0
$$

Zakres 3.Położenie maksymalnej objętości. Przy większych ciśnieniach tłok osiaga w przybliżeniu maksymalne wychylenie, zakłada się w tym zakresie liniową sztywność tłoka. Siła tłoka ma postać: 
$F_{c i}=\left(p_{c i}-p_{a t m}-p_{x \max }\right) \cdot A$

gdzie:

$\mathrm{p}_{\text {atm }}$ - ciśnienie atmosferyczne,

Równania termodynamiczne przyjmują postać, jak dla Zakresu 2.

\subsubsection{Cylinder uogólniony}

Cylinder ten, o nazwie CYLU, jest rozbudowaną wersją modelu cylindra hamulcowego i również stanowi kompletny zespół. Pominięto masowe siły bezwładności, natomiast uwzględniono siłę tarcia. W części termodynamicznej modelu uwzględniono wymianę ciepła gazu zamkniętego wewnątrz cylindra ze ściankami cylindra i otoczeniem zakładając, że ścianki cylindra mają temperaturę otoczenia. Istnieje możliwość bardziej dokładnego zamodelowania zespołu cylindra dodając inne elementy pakietu BLOK, np. siły bezwładności czy rozwinięte modele tarcia.

Model cylindra (indeks cu) posiada trzy zakresy pracy. Równania identyczne $\mathrm{z}$ opisanymi $\mathrm{w}$ punkcie 5.2.5 i 5.2.6 modelami cylindrów nie zostały powtórnie przedstawione.

Zakres 1. Zakłada się dodatkowo wymianę ciepła gazu z otoczeniem.

Zakres 2. Położenie tłoka $\mathrm{w}$ trakcie jego ruchu wynika $\mathrm{z}$ równowagi sił.

Objętość cylindra wynosi:

$$
V_{c u}=\left(x_{0}+x\right) \cdot A
$$

Równanie przyrostu gęstości przyjmuje postać:

$$
\dot{\rho}=\frac{\dot{m}}{V_{c u}}-\frac{\rho_{c u}}{V_{c u}} \dot{V}_{c u}=\frac{\dot{m}}{V_{c u}}-\rho_{c u} \frac{\dot{x}}{x+x_{0}}
$$

Równanie energii jest następujące:

$m \cdot \frac{R}{\kappa-1} \cdot d T=\dot{q} \cdot d t+\dot{m}_{w} \cdot \frac{\kappa}{\kappa-1} \cdot R \cdot T_{w} \cdot d t-$

$-p_{c u} \cdot d V_{c u}$

a po uwzględnieniu pochodnych względem czasu i uporządkowaniu otrzymuje się:

$\dot{p}_{c u}=\frac{\kappa-1}{V_{c u}} \dot{q} \cdot+\dot{m}_{w} \cdot \frac{\kappa}{V_{c u}} \cdot R \cdot T_{w}-\frac{\kappa \cdot p_{c u}}{x+x_{0}} \dot{x}$

gdzie:

$\dot{q}=c \cdot\left(T_{s}-\frac{p_{c u}}{\rho_{c u} \cdot R}\right)$

Występowanie sił tarcia $\mathrm{w}$ trakcie ruchu tłoka powoduje konieczność rozwiązania również równania sił układu. Przyjmuje ono (z pominięciem siły bezwładności) postać:

$$
p_{c u} \cdot A=S_{0}+c \cdot x+\mu_{0}\left(\dot{x}, p_{c u}\right)+\mu_{1}\left(p_{c u}\right) \cdot \dot{x}
$$

Uszczelnienia cylindra hamulcowego posiadają taką formę geometryczną, że wartość siły tarcia tłoka o obudowę zmienia się wraz $\mathrm{z}$ ciśnieniem powietrza $\mathrm{w}$ cylindrze. Wielkości: $\mu_{0}\left(\dot{x}, p_{c u}\right)$ - siły tarcia statycznego oraz $\mu_{1}\left(p_{c u}\right)$ współczynnik tarcia wiskotycznego są liniową funkcją ciśnienia (z zadaną wartością początkową). Jeżeli zada się zerowe wartości współczynnika tarcia, to rozwiązywane są równania uproszczone.

Zakres 3. Przy wyższych ciśnieniach w cylindrze i wysunięciu tłoka do zetknięcia par ciernych hamulca na kołach, tłok doznaje ograniczenia ruchu. W przypadku założenia braku dalszego ruchu tłoka równanie przyrostu gęstości przyjmuje postać

$\dot{\rho}_{c u}=\frac{\dot{m}}{V_{c u}}$

$\mathrm{Z}$ równania energii (52) po przekształceniu otrzymuje się:

$$
\begin{aligned}
& \dot{p}_{c u}=\frac{\kappa-1}{V_{c u}} \dot{q} \cdot+\dot{m}_{w} \cdot \frac{\kappa}{V_{c u}} \cdot R T_{w}=\frac{\kappa-1}{V_{c u}} \dot{q}_{c u} \cdot+ \\
& +\dot{m}_{w} \cdot \frac{\kappa}{V_{c u}} \cdot \frac{p_{w}}{\rho_{w}}
\end{aligned}
$$

Przy założeniu odkształcalności układu dźwigniowego hamulca przyjęto $\mathrm{w}$ Zakresie 3 liniową sztywność tłoka (znacznie większą, niż w Zakresie 2); równania układu przyjmuja postać, jak dla Zakresu 2.

\subsection{Dodatkowe elementy pneumatyczne}

\subsubsection{Przyrównanie parametrów gazu $\mathrm{w}$ dwóch punktach}

Zadaniem bloku (ROWNOSCP) jest przyrównanie zmiennych stanu gazu dwóch punktów bez liczenia przepływu między tymi punktami. Pozwala to $\mathrm{w}$ pewnych sytuacjach na uproszczenie modelu.

\subsection{2. Źródła ciśnienia i gęstości gazu}

W układach pneumatycznych występują często sterowania stałym lub zmiennym $\mathrm{w}$ czasie ciśnieniem niezależnym od stanu analizowanego układu. Źródło o niezmiennym w czasie ciśnieniu gazu (ZRODLOP) jest procedurą zadającą niezmienne w czasie ciśnienie i gęstość na początku każdego kroku obliczeń. Zastosowanie tej procedury zwiększa przejrzystość opisu modelu. 
Źródło o zmiennym w czasie ciśnieniu i gęstości (ZRODPNL) zadaje te zmienne jako linearyzowane odcinkowo między zadanymi chwilami czasu. Jest to przydatna procedura, zwłaszcza gdy modeluje się układ będący fragmentem większej całości. Wtedy oddziaływanie reszty układu jest zmiennym w czasie ciśnieniem, co pokazano na rys. 4.

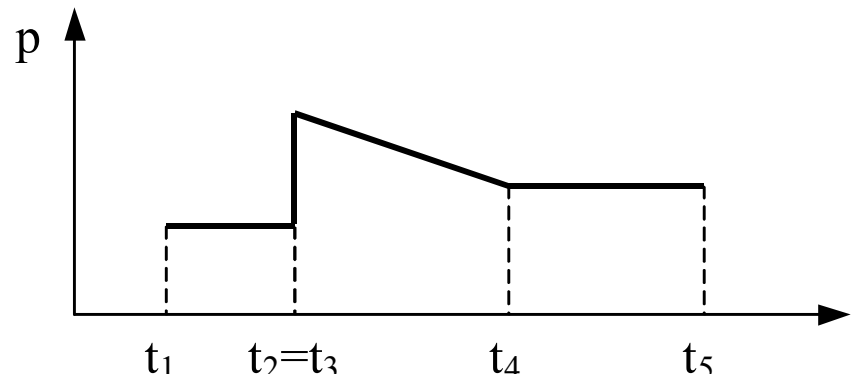

Rys. 4. Przykład źródła zmiennego w czasie ciśnienia

\subsubsection{Zmienny $w$ funkcji czasu przelot}

Blok o nazwie ZM-PRZEK umożliwia zmianę przekroju elementu przepływowego $\mathrm{w}$ funkcji czasu $\mathrm{w}$ sposób skokowy lub liniowy w zadanym przedziale czasu. Jest to funkcja uniwersalna, gdyż może sterować zmianą przekroju wykorzystanego nastepnie $\mathrm{w}$ dowolnym elemencie opisu dławienia przepływu.

\subsubsection{Bezinercyjny przekładnik}

Pakiet BLOK umożliwia modelowanie bardzo rozbudowanych przekładników ciśnienia łącznie $\mathrm{z}$ analizą dynamiki układu. Wymaga to jednak skomplikowanego modelowania. W związku z tym utworzono również prostszy model przekładnika (o oznaczeniu PRZEKL1), bazujący tylko na równowadze quasistatycznej sił działających na układ membran i sprężyny, otwierający stopniowo jeden $\mathrm{z}$ dwóch zaworów działających na typowej w aparaturze hamulcowej zasadzie trzona drążonego. Na wyjściu z procedury otrzymuje się parametry strumieni powietrza $\mathrm{w}$ obu sterowanych wewnętrznie przelotach i dodatkowo wartość przemieszczenia trzona drążonego oraz dwóch analogowych sygnałów sterujących (rys.5).

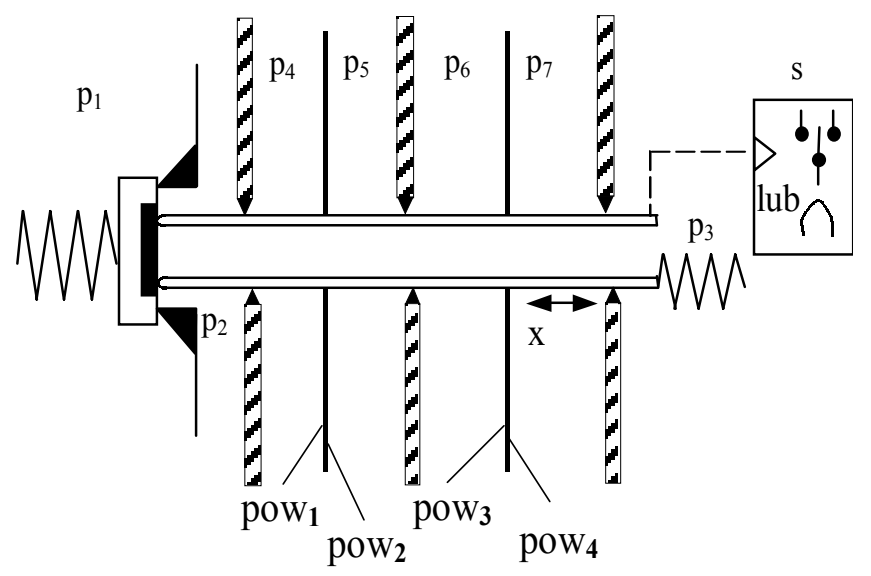

Rys. 5. Schemat działania bloku PRZEKL1
Siła wypadkowa powstała na skutek działania ciśnień na membrany wynosi:

sita pneumatyczna $=p_{4}$ pow $_{1}+p_{5}$ pow $_{2}+p_{6}$ pow $_{3}+p_{7}$ pow $_{4}$

gdzie:

$$
\begin{aligned}
\mathrm{p}_{1} \div \mathrm{p}_{T} & \text { ciśnienia } \mathrm{w} \text { komorach przekładnika wg } \\
& \text { rys. } 5, \\
\text { pow }_{1} \div & \text { pow } \\
& \text { bran wg rys. } 5 .
\end{aligned}
$$

Kierunki działania sił membran zadawane sa w danych wejściowych. Siły w sprężynach są liniowo zależne (z uwzględnieniem napięcia wstępnego) od przemieszczenia trzona drążonego. W zależności od sumarycznej sily membran otwiera się stopniowo jeden (lub w środkowym zakresie sił żaden) z przelotów tworząc proporcjonalny zawór trójdrożny. Przemieszczenia trzona są ograniczone zderzakami.

Zależności matematyczne przepływu powietrza przez zawory w tym przekładniku przyjęto jak dla dyszy adiabatycznej o zmiennym przekroju (zależnym od otwarcia jednego z zaworków) $\mathrm{z}$ uwzględnieniem przesunięcia punktu krytycznego (jak dla bloku ZAWOR). Charakterystykę otwarcia takiego przekładnika pokazano na rys. 6 .

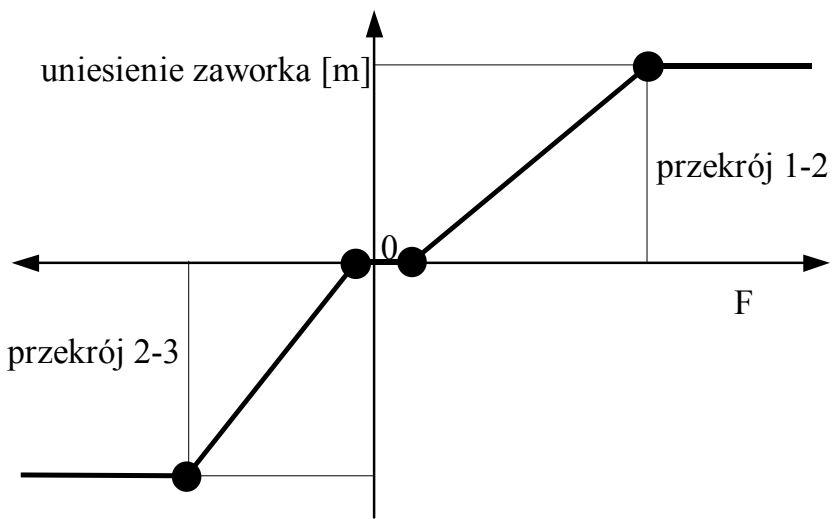

Rys. 6. Charakterystyka otwarcia przekładnika PRZEKL1

\subsubsection{Sprężarka}

Element ten modeluje zasilanie układu sprężarką o stałym w czasie jej pracy wydatku masowym, załączaną dwoma wyłącznikami krańcowymi ciśnienia. Model sprężarki o stałym wydatku masowym niezależnym od ciśnienia wyjściowego $\dot{m}_{s}$, a objętościowym zależnym, odpowiada większości sprężarek kolejowych. Procedura nosi nazwę SPREZARK. Główna zależność modelu ma postać:

$$
\dot{E}=\frac{\kappa}{\kappa-1} \dot{m}_{s} \cdot T_{o} \cdot R
$$

Dodatkowo stan załączenia sprężarki jest sygnalizowany w zadanym kanale sterującym.

\subsection{Elementy sterujące $w$ układzie pneumatycz- nym \\ Elementy sterujące przepływem $\mathrm{w}$ zależności od wartości sygnału sterującego są typowymi układami sterowania. W związku z pojawieniem się w układach}


hamulcowych elementów automatyki sterowanych elektrycznie zamodelowano także elektrozawory. Do opisu przepływów w kanałach zaworów wykorzystano zależności przepływu dla dyszy adiabatycznej wg punktu 5.1.2.

\subsubsection{Zawór trójdrożny sterowany różnicą dwóch ciśnień}

Jest to model typowego zaworu sterującego 2/3 pneumatyki (nazwanego ZAW_CIS2), sterowanego dwoma ciśnieniami, posiadający dwa położenia, trzy przyłącza i dwa przeloty. Schemat tego zaworu pokazano na rys. 7.

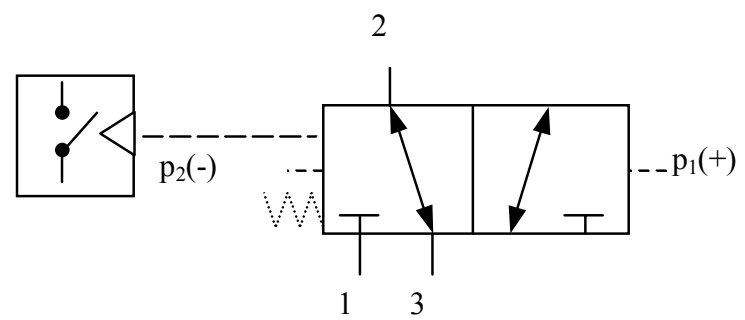

Rys. 7. Schemat zaworu sterowanego różnicą dwóch ciśnień

Dodano dodatkowe załączanie sygnału sterującego. Ciśnienie sterowania można zastąpić siłą w sprężynie.

\subsubsection{Zawór trójdrożny sterowany czterema ciśnieniami}

Zawór $2 / 3$ sterowany jest zależnością czterech ciśnień, posiada dwa przeloty: 1-2 i 2-3 (nazwany ZAW_CIS4). Załączenie zaworu (i otwarcie przepływu 12) nastepuje przy $p 1+p 2-p 3-p 4>0$. Dodatkowo następuje załączanie sygnału sterującego. Zawory sterowane różnicą więcej niż dwóch ciśnień stosowane są czasami $\mathrm{w}$ aparaturze hamulcowej. Schemat tego zaworu pokazano na rys. 8 .

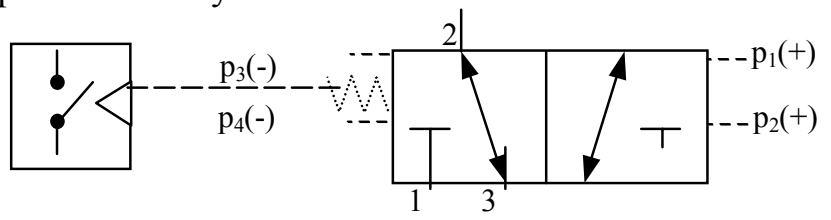

Rys. 8. Schemat zaworu sterowanego czterema ciśnieniami

\subsubsection{Zawór trójdrożny sterowany elektrycznie}

Jest to model typowego zaworu sterującego pneumatyki w układzie $2 / 3$, posiadający dwa nastawienia $i$ trzy przyłącza, nosi on nazwę ZAW_STE (rys. 9). Zawór załączany jest sygnałem sterującym zadanego kanału sterowania (ustawianym $\mathrm{w}$ jednej $\mathrm{z}$ odrębnych procedur).

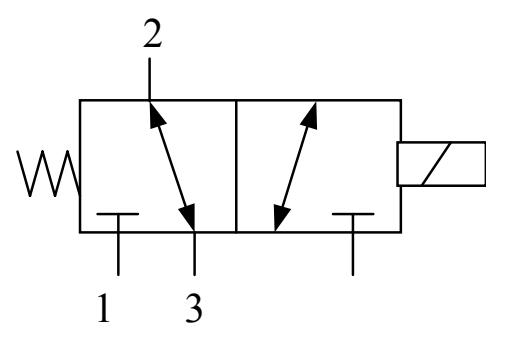

Rys. 9. Schemat zaworu sterowanego sygnałem elektrycznym

\section{Opis elementów mechanicznych}

Cechy układu hamulcowego powodują, że zmienne mechaniczne układu hamulcowego, np. otwarcia zaworów, suwaków, przesunięcia cylindrów, przekładników, dźwigni, membran przyjmują nie tylko wartości dwustanowe, ale w części przypadków dowolne (analogowe).

Cechami charakterystycznymi omawianego układu mechanicznego sa:

- poruszanie się mas tylko w jednym kierunku,

- niewielkie wielkości przemieszczeń, rzędu kilku milimetrów (oprócz cylindrów, czy siłowników, w których przemieszczenia mogą osiągnąć wartość kilkunastu centymetrów),

- stosunkowo małe prędkości ruchu tłoków; niekiedy jednak masy elementów ruchomych $\mathrm{w}$ porównaniu z siłami składowymi działającymi na te elementy są niewielkie (np. lekki zawór przesuwany siłami działającymi na membrany o dużych powierzchniach), co może stwarzać problemy numeryczne i wymaga znacznego zmniejszenia kroku obliczeń lub np. dokładniejszego modelowania thumienia.

\subsection{Membrana}

Procedura MEMB wylicza siłę działającą na układ mechaniczny wywołaną działaniem ciśnienia na powierzchnię. Ponieważ mogą istnieć najróżnorodniejsze warianty zabudowy takiego układu, zaimplementowano wersję, w której oblicza się siłę działającą tylko na jedną powierzchnię, a procedurę wywołuje się tyle razy, ile jest powierzchni. Wartość siły jest obliczana wzorem:

$$
F=p \cdot p o w
$$

\subsection{Inercja (element masowy)}

W pakiecie BLOK przyjęto konwencję, że każdy element (o właściwościach określanych jego modelem) jest wołany odpowiednią procedura, dlatego też również masa ruchoma (inercja) wywoływana jest swym blokiem INER. Obliczenia dokonuje się zależnością

$$
\ddot{x}_{k}=\frac{F_{k}}{\operatorname{masa}_{k}}
$$

gdzie: ${ }_{\mathrm{k}}$ - indeks k-tej masy.

\subsection{Sprężyna}

Procedura SPREZYNA modeluje nieliniowy element sprężysty $\mathrm{z}$ dodatkowym thumieniem, np. sprężyny śrubowe posiadające liniowe charakterystyki i i niewielkie tłumienie, a także sztywniejsze membrany. $\mathrm{W}$ układach hamulcowych sprężyny posiadają często napięcie wstępne oraz pewien obszar przemieszczenia bez kontaktu siłowego. Możliwości te zostały uwzględnione w modelu, co przedstawiono na rys. 10 . 


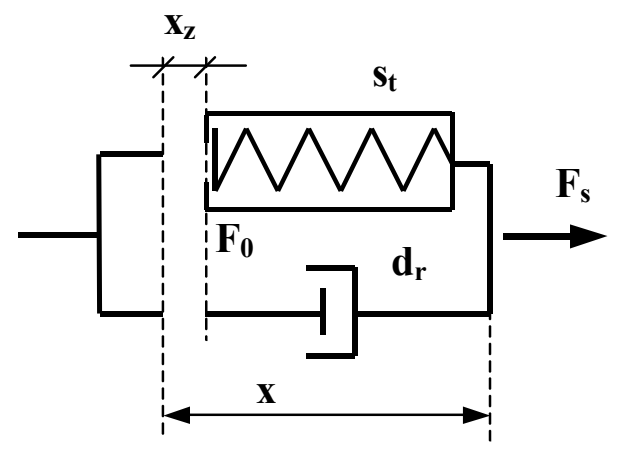

Rys. 10. Model sprężyny

Dla zakresu uginania sprężyny $\left(x-x_{z}>0\right)$ wartość siły określona jest zależnością:

$$
F_{s}=F_{o}+d_{r} \cdot \dot{x}+s_{t} \cdot x
$$

gdzie:

$F_{0}$ - napięcie wstępne,

$F_{s}$ - siła całkowita w elemencie „sprężyna”.

Dla zakresu ugięcia, w którym siła $\mathrm{w}$ sprężynie nie oddziaływuje na zewnątrz, siła thumienia wiskotycznego jest też zerowa. Zakres charakterystyki statycznej i warianty modelu przedstawiają rysunki 11 i 12.

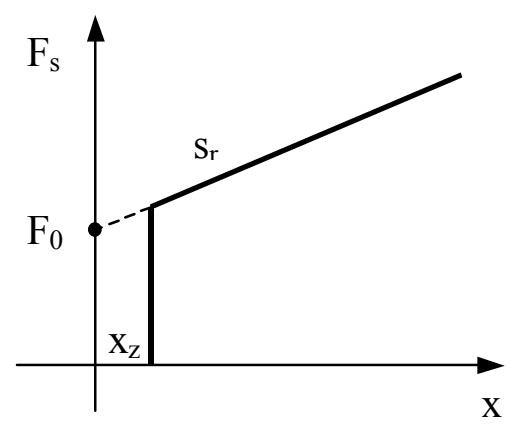

Rys. 11. Quasistatyczna charakterystyka elementu sprężystego SPREZYNA

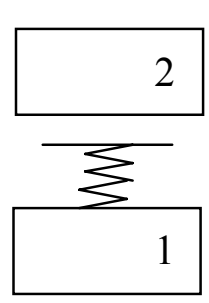

lub

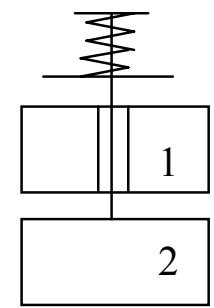

1 i 2 - oznaczenia mas

Rys. 12. Warianty modelu sprężyny

\subsection{Tarcie suche (Coulomba) z podatnością szere- gową}

Tarcie Coulomba z podatnością szeregową modelowane jest $\mathrm{w}$ pakiecie BLOK jako procedura o nazwie OPORS. Bazuje ona na modelu przedstawionym na rys. 13 , przy czym $\mathrm{x}_{\mathrm{s}}$ staje się zmienną dodatkową.

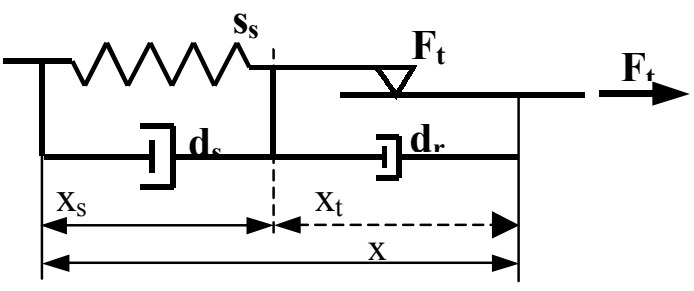

Rys. 13. Model elementu ciernego w procedurze OPORS

Oprócz elementu ciernego model zawiera sztywność szeregową $s_{s}$ połączoną równolegle z thumieniem wiskotycznym $d_{s}$. oraz dodatkowo równolegle z elementem ciernym thumik wiskotyczny $d_{r}$. Tarcie jest typu Coulomba z charakterystyką:

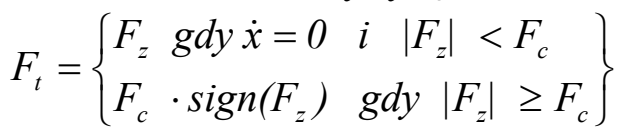

gdzie:

$\mathrm{F}_{\mathrm{t}}$ - siła tarcia,

$\mathrm{F}_{\mathrm{z}}$ - siła wejściowa działająca na element cierny gdy $\dot{x}=0$,

$\mathrm{F}_{\mathrm{c}}$ - siła tarcia Coulomba,

$\mathrm{F}_{\mathrm{ts}}$ - siła wyjściowa elementu tarcia suchego.

$\mathrm{Z}$ idei elementu wynika, że

$$
\begin{aligned}
& x=x_{s}+x_{t} \\
& F_{t s}=x_{s} \cdot s_{s}+\dot{x}_{s} \cdot d_{s}=F_{t}+\dot{x}_{t} \cdot d_{r}
\end{aligned}
$$

Zależności matematyczne układu można podzielić na dwa przedziały w zależności od siły wypadkowej [6].

Model posiada jeden stopień swobody (dodatkowy) - deformację sprężyny szeregowej. Sprężyna szeregowa jest liniowa, a thumik wiskotyczny.

Układ z elementami szeregowymi pozwala uniknąć nieciagłości przemieszczenia w funkcji siły, lepiej odwzorowuje rzeczywistość i jest o wiele bardziej stabilny numerycznie od modelu bez podatności szeregowej.

Próbne obliczenia wykazały stabilność metody i nie przekraczanie wartości maksymalnych siły tarcia nawet wtedy, gdy ugięcie elementu ciernego w pojedynczym kroku obliczeń przekracza maksymalne ugięcie sprężyny. Wartość współczynnika thumienia $d_{r}$ może być zarówno dodatnia, jak i ujemna. Wartość ujemna umożliwia rozróżnienie tarcia statycznego od tarcia Coulomba, a wartość dodatnia modelowanie efektu Stribeck'a.

\subsection{Tarcie Lund-Grenoble}

Dynamiczny model tarcia o nazwie LundGrenoble (rys. 14) jest jedną $\mathrm{z}$ najnowszych metod modelowania tarcia [5]. Przedstawiono go $\mathrm{z}$ oryginalnymi oznaczeniami. Bazuje on na przyjęciu na powierzchni stykających się ciał włosowych elementów sprężystych doznających najpierw ugięcia sprężystego 
(z), a po przekroczeniu wartości siły tarcia statycznego ślizgających się po powierzchni styku. Rozróżnia on siłę tarcia statycznego od siły tarcia Coulomba. Model (OPORLuGr) posiada $\mathrm{w}$ takim przypadku formę:

$$
\begin{aligned}
& \frac{d z}{d t}=v-\sigma_{0} \frac{|v|}{g(v)} z \\
& g(v)=\alpha_{0}+\alpha_{1} e^{-\left(v / v_{0}\right)^{2}} \\
& F_{L G}=\sigma_{0}+\sigma_{1} z+\alpha_{2} v
\end{aligned}
$$

gdzie:

$$
\begin{array}{ll}
\mathrm{F}_{\mathrm{LG}} & \text { - siła w elemencie Lund-Grenoble } \\
z & - \text { średnie ugięcie włosków } \\
\alpha_{0} & - \text { nadwyżka siły tarcia statycznego } \\
\alpha_{1} & - \text { siła tarcia Coulomba } \\
\alpha_{2} & - \text { współczynnik tłumienia } \\
v & - \text { względna prędkość tarcia włosków } \\
v_{0} & - \text { prędkość odniesienia tarcia włosków } \\
\sigma_{0} & - \text { sztywność włosków } \\
\sigma_{1} & - \text { tłumienie odkształcenia włosków }
\end{array}
$$

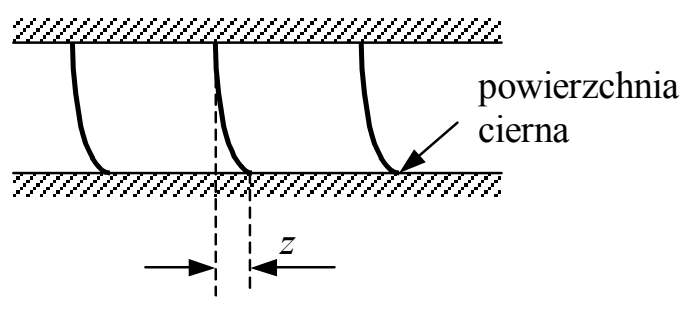

Rys. 14. Model tarcia LuGre

Zależności obu przedstawionych na rys. 13 i 14 modeli tarcia mają pewne podobieństwa. Model LundGrenoble jest bardziej rozwinięty, jednak dla pewnych parametrów symulacji może się okazywać niestabilny.

\subsection{Tłumienie wiskotyczne $\mathrm{z}$ podatnością szere- gową}

Tłumienie wiskotyczne z podatnością szeregową zamodelowane jest jako procedura o nazwie OPORW. Bazuje ona na modelu przedstawionym na rys. 15.

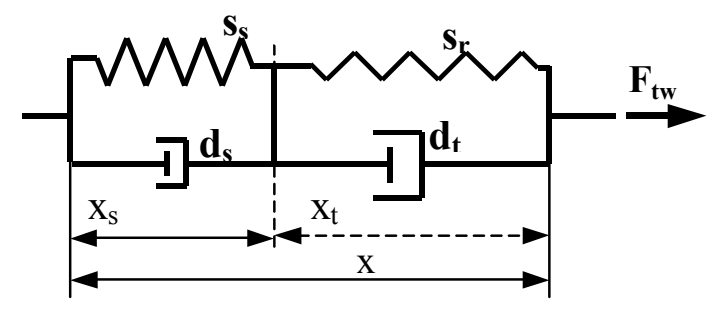

Rys. 15. Model thumika wiskotycznego w procedurze OPORW

Prezentowany model tłumika jest rozwinięciem modelu standardowego. Zastosowano $\mathrm{w}$ nim dodatkowo thumienie $d_{s}$ równoległe do sztywności szeregowej $s_{s}$. Model posiada jeden stopień swobody - ugięcie sprężyny szeregowej. Zasadniczy tłumik $d_{t}$ może posiadać charakterystykę jednokrotnie załamaną, pozostałe elementy są liniowe.
Końcowe zależności matematyczne modelu są następujące:

$$
\begin{aligned}
& \dot{x}_{s}=\frac{-s_{s} \cdot x_{s}+d_{t} \cdot \dot{x}+s_{r} \cdot\left(x-x_{s}\right)}{d_{t}+d_{s}} \\
& F_{t w}=s_{s} \cdot x_{s}+\dot{x}_{s} \cdot d_{s}
\end{aligned}
$$

gdzie:

${ }_{\mathrm{tw}}$ - indeks thumika wiskotycznego.

Gdy w parametrach modelu zada się brak sztywności szeregowej, uruchamia się uproszczony model thumika z załamaną charakterystyką tłumienia, bez sztywności szeregowej, wg rys. 16.

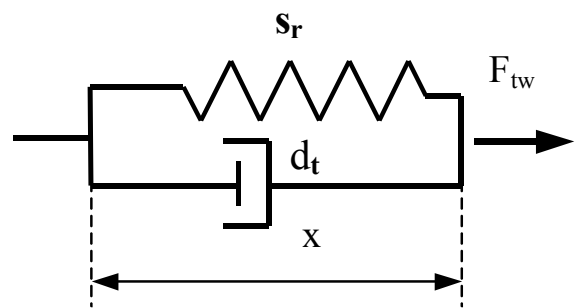

Rys. 16. Model tłumienia bez sztywności szeregowej

Siła przenoszona przez element wynosi w tym przypadku:

$$
F_{t w}=d_{t} \cdot \dot{x}+s_{r} \cdot x
$$

\subsection{Dźwignia}

Procedura DZWIGNIA modyfikuje działanie siły składowej na daną masę do postaci:

$$
F c_{k}=\text { dzwignia } \cdot F_{i}
$$

Przełożenie dźwigni dźwignia może przyjmować dowolną wartość dodatnią lub ujemną w zależności od konstrukcji układu.

\section{8.Źródła sily}

Procedury ZRODLOS i ZRODSNL umożliwiaja wstawienie $\mathrm{W}$ procesie symulacyjnym stałej lub zmiennej w czasie (linearyzowanej odcinkowo) sily zewnętrznej. Zasada tworzenia siły jest podobna, jak dla źródła ciśnienia.

\section{9.Źródła przemieszczenia}

Dwie procedury służą do zadawania wartości przemieszczenia w układzie mechanicznym. Procedura ZRODLOX zadaje stałe przemieszczenie, a ZRODXNL przemieszczenie zmienne $\mathrm{w}$ czasie, zlinearyzowane odcinkowo i wyłączalne w dowolnej chwili. ZRODXNL pozwala symulować np., sterowanie dwupozycyjne, skokowe lub liniowo zmienne.

\subsection{Ogranicznik ruchu (zderzak)}

Procedura ZDERZ modeluje ograniczniki ruchu występujące praktycznie we wszystkich aparatach pneumatycznych. Ponieważ są to przeważnie elementy obudowy metalowej, przyjęto całkowite rozproszenie energii zderzenia. Częścią procedury jest wyliczenie długości zmiennego kroku obliczeń do osiągnięcia momentu, w którym masa osiagnie styk ze zderzakiem. 


\subsection{Zblokowanie ruchu dwóch mas}

Zblokowanie ruchu dwóch mas w pewnym zakresie ich przemieszczeń (nazwane ROWNOSCX) spotyka się często w zaworach hamulcowych. Zblokowanie to może zachodzić dla różnych zakresów ruchu i algorytm uwzględnia te możliwości. Warianty zblokowania ruchu mas przedstawiono na rys. 17. a)

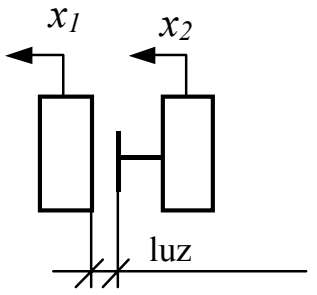

b)

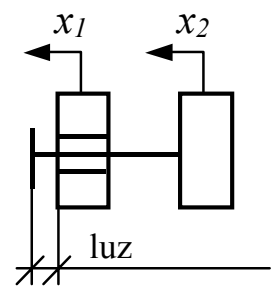

Rys. 17. Różne warianty zblokowania ruchu mas

Podobnie jak dla procedury zderzenia, założono zderzenie sztywne między masami i pełne rozproszenie energii zderzenia. W przypadku osiaggnięcia styku ciał, poruszają się one razem aż do momentu rozłączenia wynikającego $\mathrm{z}$ zależności siłowych. $\mathrm{Z}$ równania ruchu obu mas można obliczyć chwilę zderzenia i uwzględnić w metodzie zmiennokrokowej.

\section{Opis elementów generacji i modyfikacji sygna- lów sterujących}

Utworzenie bloków przetwarzania elektrycznych sygnałów sterowania funkcjami logicznymi stało się niezbędne, gdyż w układzie hamulcowym zaczyna się coraz szerzej stosować sterowanie elektrycznopneumatyczne, w którym sygnały elektryczne są częściowo utworzone przez układ pneumatyczny bądź elektryczny (np., sterowniki mikroprocesorowe), modyfikowane elektrycznie, a nasteppnie wykorzystywane do sterowania pneumatycznego.

Sygnały sterowania mogą być analogowe lub dyskretne. Aby nie zwiększać złożoności programu, te same kanały mogą służyć do przekazywania sygnału analogowego w zakresie 0 do 1 , jak i sygnału dyskretnego o wartościach $0 \mathrm{i} 1$; wszystkie procedury załączające są do tego przystosowane. Przełączenie dyskretne jest realizowane następująco: jeżeli $z_{i}<0,5$, interpretowane jest jako zero logiczne, jeżeli $z_{i}>0,5$ interpretowane jest jako jedynka logiczna.

\subsection{Zmienny w czasie sygnal sterowania}

Procedura o nazwie ZMSTER powoduje ustawienie zmiennego $\mathrm{w}$ czasie sygnału sterowania w celu jego wykorzystania $\mathrm{w}$ innych procedurach. Ponieważ sygnał sterujący umożliwia sterowanie elementów wykonawczych zarówno proporcjonalnych (analogowych), jak i dyskretnych (zero-jedynkowych), procedura dostosowana jest do obu tych typów sterowań.

Tworzony sygnał sterowania jest skokiem lub linią łamaną, linearyzowaną między punktami charakterystycznymi na osi czasu. Dla czasu przed pierwszym punktem danych posiada wartość zero, dla czasu poza ostatnim punktem danych sygnał posiada ostatnią wartość danych. Przykład utworzonego sygnału pokazano na rys. 18 .

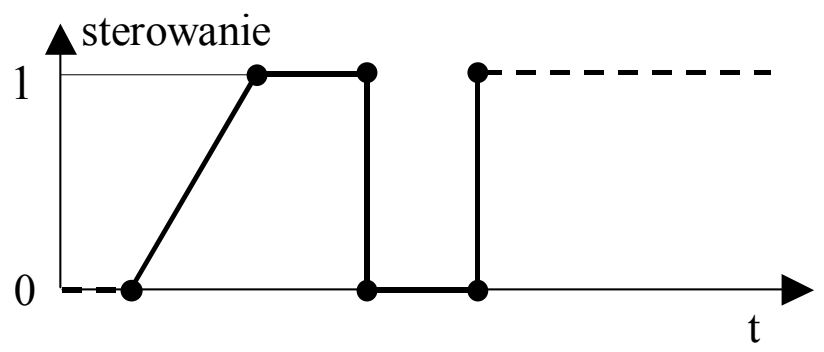

Rys. 18. Przykład sygnału sterowania

\subsection{Generator sterowania impulsowego}

Jedną $\mathrm{z}$ możliwości wysterowania szybkości zmian układu analogowego elementami dyskretnymi jest impulsowe sterowanie układem. W tym celu utworzono blok STIMPULS umożliwiający symulację sterowania impulsowego o stałej częstotliwości i stałym procentowym wypełnieniu cyklu. Przykładowo dobierając obie te wartości dla sygnału otwarcia elektrozaworu, można zmieniać gradient zmian ciśnienia $\mathrm{w}$ zbiorniku $\mathrm{w}$ czasie i regulować dokładność sterowania. Wyjściem z podprogramu jest skokowo zmienna wartość sterowania (lp. 6b w tabeli 1) załączana w każdym cyklu na czas równy długości wypełnienia impulsu.

\subsection{Opóźnienie sterowania}

Jest to funkcja logiczna ( o nazwie OPSTE) o jednym wejściu i jednym wyjściu. Wyjściem jest wartość funkcji wejściowej opóźniona o zadany czas. Na początku symulacji, dla czasu symulacji mniejszego niż wymagany dla wprowadzenia opóźnienia sterowania, wartość wyjściowa jest wartością początkową (lp. 6c w tabeli 1).

\subsection{Sterowanie o zadanej długości czasu}

Jest to funkcja logiczna (nazwa DLSTE) o jednym wejściu i jednym wyjściu. Przekazuje ona sygnał wejściowy na wyjście tylko w zadanej długości czasu, a potem go zeruje (lp. $6 \mathrm{~d} \mathrm{w}$ tabeli 1 ).

\subsection{Elementy logiczne}

Układy te realizuja podstawowe funkcje logiczne, w których na wejściu podawane są jeden lub dwa sygnały, a wyjściem jest sygnał wynikowy. Są to następujące funkcje logiczne:

- AND sygnałów sterowania (LOGAND),

- OR sygnałów sterowania (LOGOR),

- NOT sygnału sterowania (LOGNOT),

- XOR sygnałów sterowania (LOGXOR).

Sygnał sterowania może przenosić zarówno sygnał dyskretny jak i ciagly. Dla operacji logicznej AND operacja przyjmuje postać $s_{k}=s_{i} . s_{j}$, dla operacji OR postać $s_{k}=s_{i}+s_{j}$, dla operacji NOT postać $s_{k}$ $=-s_{i}+1$, dla operacji XOR postać $s_{k}=a b s\left(s_{i}-s_{j}\right)$, gdzie $s_{i}$ i $s_{j}$ są sygnałami wejściowymi, $s_{k}$ jest sygnałem wyjściowym. Taki zapis operacji w postaci liczb 
rzeczywistych pozwala zachować zgodność dla wartości binarnych, a dla wartości rzeczywistych pozwala na różnorodne wykorzystanie tych sygnałów.

\section{Zakończenie}

Przedstawiono zależności teoretyczne i procedury sterujące opracowanej metody analizy dyskretnych układów pneumatyczno-mechaniczno-elektrycznych. W celu zaprezentowania całej metody symulacyjnej ograniczono uzasadnienia przyjętych zależności modelowania. Przykłady modelowania konkretnych zespołów kolejowych układów hamulcowych oraz weryfikacji doświadczalnej zostaną zaprezentowane w kolejnych publikacjach. Przedstawiona metodyka modelowania została wykorzystana utylitarnie w kilku pracach, przykładowo $\mathrm{w}$ [7, 8, 9 i 10].

Prezentowana metoda może dotyczyć również symulacji na etapie projektowania. Przy jej użyciu można rozpatrywać warianty konstrukcji w celu wybrania najlepszego rozwiązania. Dokładność wyników zależy jednak od uszczegółowienia projektu, np. projekt wstępny da tylko wstępne wyniki symulacyjne.

Przedstawione elementy modelowania winny wystarczyć do zapewnienia możliwie dokładnego, lub z założenia uproszczonego, opisu układu rzeczywistego hamulca pneumatycznego na pojeździe szynowym. Inwencja konstruktorów może jednak spowodować konieczność utworzenia dodatkowych elementów modelu.

\section{Literatura}

[1] Benedict R. P.: Fundamentals of pipe flow. John Wiley \& Sons, Nowy Jork, 1980.

[2] Dejc M. E.: Techničeskaja gazodinamika. Energia, Moskwa 1974.

[3] Gasowski W., Piechowiak T.: Problemy przeptywu powietrza $w$ uktadzie hamulcowym pociqgu. Pojazdy Szynowe, nr 1/2003.
[4] Gasowski W., Piechowiak T.: Matematyczny opis zjawisk zachodzacych w uktadzie pneumatycznym hamulca pociagu. Pojazdy Szynowe, nr 1/2004.

[5] Olsson H., Aström K.J., Canudas de Wit C., Gäfvert M., Lischinsky P.: Friction Models and Friction Compensation. European Journal of Control, $n r$ 4/1998.

[6] Piechowiak T.: Modelowanie uktadu mechanicznego $w$ urzadzeniach pneumatycznych hamulca. Pojazdy Szynowe, nr 3-4/2004.

[7] Piechowiak T.: Model matematyczno-fizyczny przetwornika elektro-pneumatycznego opartego na pojemności $i$ dwóch zaworach elektropneumatycznych sterowanych binarnie. Instytut Pojazdów Szynowych Poznań. OR-8237 (niepublikowane), 2000r.

[8] Piechowiak T.: Dobór parametrów konstrukcyjnych przektadnika do napetniania przewodu głównego na podstawie obliczeń gazodynamicznych oraz badań modelu przektadnika $w$ aspekcie spetnienia wymagań podanych $w$ karcie UIC 541-03. Instytut Pojazdów Szynowych Poznań, OR-8337 (niepublikowane), $2001 r$.

[9] Piechowiak T.: Badania symulacyjne modelu instalacji pneumatycznej $w$ oparciu o wyniki symulacji propozycji petnego modelu systemu sterownia hamulcem pneumatycznym pociagu. Instytut Pojazdów Szynowych Poznań, OR-8511 (niepublikowane), 2002r.

[10] Piechowiak T.: Napetnianie hamulca pociagu przez lokomotywe BR 185. Instytut Pojazdów Szynowych Poznań, (niepublikowane), $2003 r$.

[11] Pogorelov B. I. L.: Gazodinamičeskie rasčety pnevmatičeskich privodov. Mašinostroenie, 1971.

[12] Tuliszka E.: Mechanika plynów. Wydawnictwo Uczelniane Politechniki Poznańskiej, Poznań 1969. 